\title{
Producing and Identifying Forgeries of Chinese Manuscripts
}

\begin{abstract}
In just a little more than two decades, from 1994 to 2015, seven public institutions in China acquired considerable numbers of unprovenanced bamboo-slip manuscripts. Following the economic upsurge the country experienced during this period, the art and antique market expanded rapidly. The artefacts that appeared on it did not always have a flawless history, though; some of them came from a flourishing industry producing and selling fakes, or even worse, from looted tombs. In the light of this development, it comes as no surprise that the authenticity of many of these manuscripts has been questioned. In order to understand how exactly judgements on the authenticity of these manuscripts were passed, it is necessary to go back to ancient and medieval ideas and practices. Traditional attitudes towards written artefacts are identified as determining modern approaches assessing and appreciating manuscripts from ancient China.
\end{abstract}

[...] calligraphy, valued for its capacity to embody in brushwork the mind and character of the individual artist, was more amenable to accurate and efficient replication than any other form of art. ${ }^{1}$

Robert E. Harrist Jr.

Manuscripts from ancient and medieval China have only been excavated in large quantities since the twentieth century. They are invaluable sources of information for scholars, and in collectors' eyes they are precious artefacts - if they

1 Harrist 2004, 32.

Note: I am grateful to Thies Staack for drawing my attention to $\mathrm{Hu}(2010)$ and to further relevant literature as well as for critically commenting on a draft of this article. Thanks to Xiaomeng He for providing a collection of early Chinese legal stipulations related to faking and forging, from which I have drawn below. For simplicity's sake, I have used traditional characters here, even in cases where the source was produced in simplified characters.

Ә Open Access. (C) 2020 Michael Friedrich, published by De Gruyter. (cc)BY-NC-ND This work is licensed under the Creative Commons Attribution-NonCommercial-NoDerivatives 4.0 International License.

https://doi.org/10.1515/9783110714333-014 
are authentic, that is. ${ }^{2}$ In 2013, prize-winning New York Times author David Barboza and his colleagues exposed the mechanisms governing the Chinese art and antique market. In their article entitled Forging an Art Market in China, they connected the artists' traditional training by copying to the modern art market:

Artists here are trained to imitate the old Chinese masters, and they routinely produce highquality copies of paintings and other works, such as ceramics and jade artifacts. That tradition has intersected with the newly attractive art market, in which reproductions that so many have the skills to create are often offered as the real thing. It would be hard to create a more fertile environment for the proliferation of fakes. ${ }^{3}$

Barboza reported on nouveaux riches and government officials buying and selling in close co-operation with auction houses and quoted a study saying 'that as many as 250,000 people in about 20 Chinese cities may be involved in producing and selling fakes', with Beijing, Tianjin, Suzhou and Nanjing being centres for replicating paintings and calligraphies, 'the workhorses of China's art market'. ${ }^{4}$

A brief look at Chinese traditions of forging written artefacts (Part 1) will serve as an introduction to more recent developments since the early twentieth century (Part 2). I shall then offer some general observations on method (Part 3). The term 'manuscript' will be used in a very general sense here to refer to handwritten artefacts, no matter whether they are works of art or shopping lists. ${ }^{5}$ In accordance with Chinese usage, traditional designations of periods will be provided as well as absolute dates, i.e. the Warring States (fifth-third centuries BCE), Qin (the state and empire up to the latter's demise in 206 BCE) and Han (Western: secondfirst centuries BCE, Eastern: first-second centuries CE).

2 Susan Whitfield meant the same thing when she said 'Dunhuang manuscripts are neither wholly akin to works of art nor to texts, but something of each'; see the introduction in Whitfield 2002, 12.

3 Barboza et al. 2013; this article was the first in the three-part series called 'A Culture of Bidding', the Chinese version of which is not accessible any more, as Thies Staack has noted.

4 Barboza et al. 2013. Part two of the series on Poly Auction, a company belonging to the stateowned military technology specialist China Poly Group and one of the major players on the Chinese art market, was not accessible.

5 See Lorusso et al. 2015. 


\section{Traditions of forgery}

Forgeries of written artefacts are occasionally mentioned in anecdotes from ancient times, but they are not a major topic, at least in the received literature. ${ }^{6}$ From Han times onwards, the histories are full of attempts to fake documents and other artefacts. Recently published manuscripts additionally provide new evidence.

\subsection{Forging: law and canon}

The expansion of territorial states from the fifth to the third century BCE, the unification of the empire by the state of Qin in 221 BCE and the establishment of the first long-lasting imperial state by the Han (202 BCE-8 CE) would not have been possible without written communication - this made effective control of the populace possible as well as the efficient administration of resources. Archaeological evidence from the Qin and Han not only demonstrates the geographical range of the early empires, but it shows how central administration penetrated the realm: imperial decisions were cascaded down to military deployments and administrative units more than a thousand miles away from the capital and, in turn, constituted the lowest level of a reporting system conveying information on all aspects relevant to higher authorities and ideally to the imperial court as well. Copying documents, either excerpting or duplicating their content in toto, was essential to the functioning of the administration and the stability of the ruling house. ${ }^{7}$ In light of the ever-growing importance of written evidence in law and administration, it does not come as any surprise that the practice of falsifying and forging documents appears to have grown along with it. A Daoist text from the second century BCE has the following lament:

蒼頴之初作書, 以辯治百官, 領理萬事, 愚者得以不忘, 智者得以志遠; 至其衰也, 為 姦刻偽書, 以解有罪, 以殺不喜。 ${ }^{8}$

When Cang Jie first created writing, it served to distinguish and regulate the Hundred Offices and to control and regulate the Ten Thousand Affairs, so that the stupid would not forget things and the intelligent would be able to achieve their far-reaching ambitions;

6 Harrist 2004, 39 quotes a famous one, with Emperor Wu (r. 140-86 BCE) identifying the forger by his handwriting.

7 See Giele 2006 for an in-depth study of Han central administration.

8 Huainan zi 淮南子2 0, by Liu An 劉安 (180-122 BCE), in Liu W. 1989, vol. 2, 673. 
when it came to its decline, it was used for treacherously and malignantly forging documents in order to set the guilty free and kill the innocent.

Legal stipulations of late pre-imperial and early imperial times (third-second centuries BCE) contain many items concerning falsifying or completely forging documents, testifying to the authorities' concern about any attempt to hamper the communication apparatus. Statutes from the early second century BCE contain articles on different types of forgery: ${ }^{9}$ a forger who had produced fake copies of the Emperor's seals, for instance, would be sentenced to death by cutting his body in two at the waist and publicly displaying the remains afterwards, and if they forged the seals of lower offices, then the offenders had to work as wallbuilders or grain-pounders for the rest of their lives. The death penalty for forging an imperial decision was only applicable if any harm had resulted from it; if that was not the case, the offender would merely be fined a certain amount of gold..$^{10}$ In general terms, the punishment for forging documents was tattooing and doing hard manual work as a wall-builder or grain-pounder for the rest of the offender's life (為偽書者: 黝為城旦春). Destroying the seal on a document that guaranteed its authenticity would also be heavily punished. ${ }^{11}$

Further evidence from legal cases dealing with 'fraudulent' ( $z h a$ 詐) producing or altering of documents confirms the relevance of these stipulations. ${ }^{12}$ The main terms used are jiao 矯 ('bend straight' > pretend to act on higher authority, mainly for $z h i$ 制, imperial decisions) and, most commonly, wei 偽 ('make believe' $>$ produced, artificial, non-genuine, mainly for shu 書, documents or writings in general).$^{13}$ According to archaeological and literary evidence, the term wei shu 偽 書always referred to forged documents at that time.

In the late first century BCE, a certain Zhang Ba 張霸 produced a forgery of a collection of archaic canonical texts called the Documents (shu 書). Probably following a call to contribute writings to the imperial court in 26 BCE, he submitted

9 From the tomb Zhangjiashan 247 (closed in 186 BCE); see Barbieri-Low/Yates 2015, 392-395. 10 Loyal generals or officials possibly faked commands because of urgency or difficulties in communication, but they were pardoned once they had been cleared of treason.

11 Barbieri-Low/Yates 2015, 428, n. 80: 'Qin and Han official documents written on wooden boards or bamboo slips were bound with a cord and sealed with a “lump of clay” (fēng 封) that received the impression of an official's seal'.

12 The 'exemplary cases' 9 to 12, also found in Zhangjiashan 247, all deal with the forgery of documents; see Lau/Lüdke 2012, 161-176 and Yates and Barbieri-Low/Yates 2015, 1245-1267. In addition, case 14 from a similar collection in the Yuelu corpus also deals with a faked document, a private letter produced in order to obtain certain benefits by fraud; see Lau/Staack 2016, 276294.

13 Unger 1989, 44 and 132. 
a collection of 102 Documents, which he had fabricated (kong zao 空造) by cutting and re-combining the 29 known chapters and mixing them with texts from other sources. The Emperor compared them with another collection of 100 Documents from his private library and found they were completely different. Although Zhang deserved the death penalty, he and his documents were spared because the Emperor liked both. ${ }^{14}$ Shortly after Zhang's failed attempt to deceive the Emperor, the ‘court librarian' Liu Xin 劉歆 (46 BCE-23 CE) tried to establish the primacy of written evidence over the oral traditions of the Confucian canon still dominant at that time, which were more prone to corruption than the former. ${ }^{15}$ His argument was based on manuscripts discovered in the imperial collection or found in other places under rather mysterious circumstances, which contained 'Confucian' texts that were unknown or only known in a different version, which is why they were called fakes by his opponents. These and other forgeries were called 'forged writings' (wei shu 偽書) or 'forged classics' (wei jing 偽經) later and sparked off a debate on the authenticity of the canonical or 'Confucian' texts, which continued right up to the twentieth century. ${ }^{16}$

The first known catalogue of Buddhist scriptures in Chinese by Daoan 道安 (312-385) used the term 'dubious sutras' (yi jing 疑經) for sutras that had not come from India in 374: 'without critical examination, there is no way of distinguishing genuine from fake (zhen wei 真偽)', he wrote. ${ }^{17}$ In addition, Sengyou 僧祐 (445518) called them 'forged sutras' or 'forged classics' (wei jing 偽經) in 515. ${ }^{18}$ In Western scholarship these Buddhist texts have been called 'apocrypha' ${ }^{19}$

With the exception of the seals and their impressions in clay as means of authentication, what all the cases presented so far have in common, regardless of whether they are legal or canonical (both Confucian and Buddhist), is that their point of departure is the text. A fake document is a material object, of course, but the material support in these cases was only a support for the relevant content. Conversely, one of the fine arts is intimately related to the written artefact.

14 Lun heng 論衡 81 by Wang Chong 王充 (27-c. 100); see Forke 1907, 448; the Documents were a favourite object of forgery; for a brief summary, see Liu G. 2016, 99-110.

15 See Loewe 2015.

16 Fischer 2008-2009 provides a short history of 'authentication studies'.

17 Chu sanzang jiji 出三藏記集 5, in Su/Xiao 1995, 222.

18 Chu sanzang jiji 5, in Su/Xiao 1995, 224.

19 See Buswell 1990. 


\subsection{Replicating: art and religion}

The art of writing or 'calligraphy' (shu fa 書法) emerged in the second century CE. Copying 'permeates nearly every aspect of this art', and by 'repeatedly copying a piece of calligraphy of another writer, a calligrapher internalizes that person's style'. In addition, copying also served to preserve and transmit earlier works. ${ }^{20}$ Apparently similar to Islamic calligraphic tradition, ${ }^{21}$ copying was therefore ambivalent: on the one hand, it served multiple honourable purposes, while on the other, copies could be used to deceive people, with a variety of purposes in mind. Robert E. Harrist Jr. distinguishes between two types of calligraphic 'forgeries': a 'good copy gone bad', i.e. a copy originally produced just as a replication of a work for study or other reasons, and 'a work that is not based on a pre-existing model, but executed in the style of another calligrapher or historical period'.22

By the fourth century at the latest, works belonging to this art had become collectibles for the rich and powerful, with an aesthetic discourse developing at the same time. The market soon attracted forgers. The imperial clansman Liu Yizong 劉義宗 (d. 444) was an admirer of the works of the famous artists Wang Xizhi 王羲之 (303-361) and his son Wang Xianzhi 王獻之 (344-386). ${ }^{23} \mathrm{He}$ publicly announced his willingness to pay any price for their works, but then:

Base fellows cunningly made copies. They used the drippings from thatched roofs to change the color of the paper and further aged it, making it like old calligraphy. Authentic and fake (zhen wei 真偽) were mixed together, and no one could tell the difference. Therefore, among works accumulated by the Marquis of Hui, there were many that were not authentic (fei zhen 非真). ${ }^{24}$

The memorial to Emperor Ming of Song 宋明帝 (r. 466-472) containing this story was submitted in 470. It was composed by $\mathrm{Yu} \mathrm{He}$ 虞棆 at the emperor's request in order to identify the authentic works and bring order to his collection.

A few decades later, Emperor Wu of Liang 梁武帝 (r. 502-549) exchanged letters with his friend Tao Hongjing 陶弘景 (456-536) on the authenticity of pieces in the very same imperial collection Yu had catalogued one dynasty and two emperors earlier. The number of forgeries had obviously grown at such a rate that almost every work was greeted with scepticism by them, with Tao serving the

20 Harrist 2004, 41-42.

21 See the contribution by François Déroche in this volume.

22 Harrist 2004, 34.

23 See Uta Lauer's contribution in this volume.

24 Harrist 2004, 39. 
emperor 'as an artistic consultant and as a copyist'. They exchanged detailed arguments as to why a piece should be considered genuine or a copy, in the latter case also trying to determine who the originator was. These copies were possibly 'good copies' or 'honest copies', ${ }^{25}$ just like those produced by Tao for personal study and appreciation. ${ }^{26}$

Tao, a Daoist polymath and calligrapher, was certainly qualified for discerning hands, not only because of his artistic family tradition, but because he had started to collect remnants of the 'Maoshan revelations' around 484; in the late fourth century, immortals had visited a certain Yang Xi 楊羲 and revealed texts and talismans to him, either by leading his hand with the brush, by dictation or by showing him heavenly scriptures which he then copied. These writings had already existed prior to the creation of the world, in a supramundane script inaccessible to human beings, and therefore had to be converted into forms manageable by them. Even these forms were only revealed to the worthy ones, however - in this case, Yang and the two disciples to whom he entrusted the manuscripts. The written artefacts as such, the 'traces of the Perfected' (zhen ji 真迹, lit. the genuine, i.e. the immortals), ${ }^{27}$ guaranteed the authenticity of the teachings. The first forgeries appeared in the early fifth century, making it increasingly difficult to identify the authentic writings. After travelling in Southern China and searching for manuscripts that were not in the imperial collection, Tao edited all the documents he thought were genuine as well as some doubtful cases. His criterion for deciding on the authenticity of a manuscript was the 'inspired hand" ${ }^{28}$ of Yang and his two disciples, who had continued to copy the revelations. In his famous work Zhen gao 真誥 ('Declarations of the Perfected'), he meticulously recorded all the material traces of the revelations, including the size and colour of the paper slips and the colour of the ink used if it was not black. ${ }^{29}$ In fact, the ritual production of apotropaic and other written artefacts still plays an important role in Daoist traditions to this day.

25 Cohen 2002, 22.

26 In Fashu yaolu 2, in Jie 1984, 45-54; see Harrist 2004, 42-46 for details.

27 The expression zhen $j i$ in contemporary usage means 'authentic traces' of an artist's hand, i.e. an original.

28 Robinet 1993, 29.

29 Strickmann 1977; Ledderose 1984; Robinet 1993, 1-18; Harrist 2004, 40-41. 


\subsection{Works of art and antiquities on the traditional market}

During the Tang period (618-907), works of the 'ancient masters' such as Wang Xizhi could earn 1,000 taels of silver on the art market, a huge sum approximately equal to the salary a lower official earnt over more than thirty years. ${ }^{30}$ Forgery of artworks gained momentum again in the late Northern Song period (960-1126). Members of a new social stratum, the shidafu 士大夫 or 'gentry', found their identity in traditional art and literature, amongst other things, including material culture as manifested in bronze vessels and stone inscriptions from the past. These objects were collected, catalogued and traded on the flourishing art and antique market. The inscriptions on bronze and stone provided new evidence of the past, and together with the emerging field of epigraphy, the study of them created new, critical approaches to the study of literary sources. Scholarly and commercial interests merged in a vogue of antiquarianism, far exceeding the former circulation of ancient calligraphies and paintings, ${ }^{31}$ which incited forgers to create fakes of bronzes with an artificial patina. ${ }^{32}$ In addition, members of the new elite not only consumed calligraphies as connoisseurs, but also produced them as the art of writing became one of the tokens of a literate and educated person. The great $\mathrm{Su}$ Shi 蘇軾 (1037-1101), famous as an upright statesman, was not only praised for his poetry and paintings, but also for his calligraphy, leading to heavy forging of his works even while he was still alive. ${ }^{33}$

During the sixteenth and early seventeenth century, famous painters and calligraphers had to hire 'ghost artists' in order to satisfy growing demand for their works. In addition, some of the celebrities forged famous works themselves, at times even adding their own colophons to those pieces, thus authenticating them. Colophons and seal impressions were an important means of authentication, as a connoisseur's seal would signify a positive assessment of the work by a known authority and attest its provenance. ${ }^{34}$ Playing with authenticity had its roots in the early phase of the art and even led to open trading in 'counterfeits by famous hands', although these works were still considered less valuable than an original. Only creations by the ghost artists producing 'original' works exactly like their masters' hands were regarded as being as good as the genuine works. At the end of the imperial period, many workshops all over the empire catered to

\footnotetext{
30 Jang 2016, 60.

31 See Falkenhausen 2013 for a general overview and Sena 2019 on bronze and stone artefacts.

32 Craddock 2016, 356-357.

33 Jang 2016, 64.

34 Fölster 2015.
} 
the needs of different groups, many of them surviving well into the Republican era. ${ }^{35}$

\section{Modern forgeries}

A new chapter in the history of copying, replicating and forging was opened in the second half of the nineteenth century when Westerners became increasingly interested in East Asian antiquities and works of art. From the late sixteenth century onwards, East Asian artefacts had found their place in the collections of the noble and rich and paved the way for the chinoiserie that characterised the eighteenth century. Since there was no expertise on these objects yet, Europeans had to rely on their taste or on locals when acquiring objects. Export industries began to spring up in the seventeenth century, producing porcelain, furniture and other handicrafts for the far Western market. The traditional Chinese arts such as calligraphy and antiquities such as bronzes were only known in general terms.

After the inglorious invasions of the imperial capital by Western powers in 1860 and 1900 and the end of the Qing dynasty in 1911, an international market developed with centres in today's Beijing and Shanghai. In the first half of the twentieth century, Chinese, Japanese and Western dealers tried to profit from the political unrest in China and acquire valuable objects to sell. At the same time, clever business people produced what the market wanted, even if it was only ceramics from late pre-imperial and Han times. ${ }^{36}$

\subsection{Medieval manuscripts from Dunhuang}

While most of the transactions took place in the treaty ports and those areas officially open to foreigners, the provinces of Xinjiang and Gansu, the Central Asian part of the empire in the northwest became a destination for expeditions by the major powers. The desert sands concealed riches in the form of manuscripts, which were excavated and sold by locals. Forgers took part in their businesses together right from the start, with a certain Islam Akhun in Kashgar, whose Indic fakes even fooled a serious scholar, being the best-known case. Akhun was finally exposed by the Hungarian-British Indologist Aurel Stein (1862-1943).

35 Jang 2016, 63-66.

36 Museum für Asiatische Kunst 2007. 
Stein worked for the government in India and was to become the first Westerner to see the famous 'library cave' in Dunhuang in 1907, which was discovered by a Daoist monk in 1899 or 1900 . On this occasion, Stein acquired a considerable amount of manuscripts. The French Sinologist Paul Pelliot (1878-1945) arrived only eight months later and also took a cache of manuscripts of a similar size with him when he returned to Europe again. In 1909, Pelliot showed some of his acquisitions to local scholars in Beijing. As a result, the Chinese authorities realised what was going on in the far West and dispatched an official to fetch the remaining contents of the cave and bring them to the capital. They arrived in 1910, but the official was arrested shortly afterwards - on charges of theft. It is still unclear who stole the manuscripts, but scholars agree that copying and forging began soon after it happened. To complicate things, the official mission to empty the cave does not seem to have been entirely successful since subsequent Japanese and Russian expeditions were still able to procure a number of such artefacts. This has led some scholars to suggest that all the objects acquired after 1910 are actually forgeries, while others maintain that most of them are genuine beyond a doubt. ${ }^{37}$

The corpus of Dunhuang manuscripts is huge; it contains tens of thousands of items. The number is difficult to determine, actually, because many of the objects are fragments. In some cases, different fragments belonging to one and the same artefact are now kept by two different institutions, so the original manuscript has effectively been scattered by collectors. The impact of the Dunhuang discovery can hardly be overestimated: large numbers of original written artefacts from the fourth to the eleventh centuries became available to scholars for the very first time. Even though the majority of them contained copies of wellknown Buddhist sutras, many of them carried texts that were still unknown at the time, dealing with religion and literature to some extent, but particularly documents concerning everyday life such as contracts. While the study of these texts largely remained in the hands of scholars, the discovery of 'real' handwriting from medieval times also appealed to a large audience of art connoisseurs. The manuscripts were hardly ever meant as works of art, it seems, but calligraphers and connoisseurs started studying and copying them nonetheless. Here we can see the same pattern as the one outlined above: in light of the surging prices for these treasures, trained calligraphers started to produce copies or fakes of them; even 'honest copies' 'went bad' sometimes. At an auction held in 2019, more than US\$580,000 was paid for a scroll from the ninth century containing notes on a Buddhist sutra. Together with the catalogue, the auction house

37 Introduction in Whitfield 2002, 1-21; Van Schaik/Galambos 2012, 13-29. 
published a volume on the Dunhuang studies of the former owner, a known scholar and collector, thus indirectly providing evidence of its authenticity. ${ }^{38}$

The reluctance on the part of institutions and individuals to admit that they spent huge sums of money on buying a forgery might, at least in part, be responsible for the delay of systematic research. Another reason, however, is probably even more important. Jean-Pierre Drège noted:

[...] that, although an examination of handwriting usually gives rise to a judgement, this often lacks any methodological basis. Palaeography as it developed in the West has no counterpart in Chinese calligraphy. In the latter case, experience becomes a substitute for method and, as a result, assessment procedures are not easily transmitted. Moreover, it is remarkable that the dating of handwriting, and consequently manuscripts, is more often than not based on styles as defined by historians of calligraphy. ${ }^{39}$

Thus the traditional calligraphic approach has dominated the approach to the study of non-calligraphic artefacts for a long time. Only in the second half of the twentieth century were attempts made to remedy this situation, with Fujieda Akira 藤枝晃 (1911-1998) and Jean-Pierre Drège taking the lead. Preliminary surveys of the whole corpus including codicological and palaeographic features have been undertaken, and initial material analyses are now available. ${ }^{40}$ Overall and in spite of the growing number of case studies, systematic research on these aspects of the Dunhuang manuscripts is still in its infancy. The situation is even less favourable for medieval written artefacts from other Central Asian sites.

\subsection{Ancient manuscripts}

In Dunhuang, ${ }^{41}$ Stein had not only acquired medieval manuscripts, but also recovered nearly 1,000 wooden and bamboo slips containing administrative documents from signal towers mainly from the first century BCE and the first century CE. In 1930, members of the Sino-Swedish expedition discovered a

38 The scroll had belonged to Zhou Shaoliang 周紹良 (1918-2005) and was described by the renowned Dunhuang scholar Fang Guangchang 方廣錩 in the catalogue; see Beijing Wulun guoji paimai youxian gongsi (2019), 14; according to an email sent on 8 October 2019 by Jiao Ao, the company's manager of rare books and manuscripts, the price including the commission for the sale was 4,025,000 yuan (almost US\$585,000 on 14 July 2019, the day of the auction). See Jiao 2019 for the accompanying volume.

39 Drège 2002, 44.

40 In addition to the contributions in Whitfield 2002, see Helman-Ważny 2016 and Drège 2017 on the history of Chinese paper.

41 For an overview of the major discoveries up to 2010, see Liu G. 2016, $27-47$. 
similar site in Juyan 居延/Etsingol yielding more than 10,000 slips and fragments. The study of these documents has remained a highly specialised field that only a handful of historians are exploring. The scribal traces on them were included in studies of the history of the script, but since they were just 'ordinary' documents, they never attracted as much attention as the literary manuscripts produced in medieval times. ${ }^{42}$

In the early 1940s, robbers looted a tomb in the southern province of Hunan and found three silk manuscripts from approximately 300 BCE, which were sold to a US soldier by a Shanghai art dealer in 1946 and are now kept in the Sackler Foundation and the Freer and Sackler Galleries respectively. ${ }^{43}$ Because of its previously unknown content, one of these manuscripts, commonly called the Chu Silk Manuscript, has received considerable scholarly attention. It was the first complete non-documentary manuscript from pre-imperial China to be seen by modern scholars. ${ }^{44}$

Due to internal strife and war, archaeological activities were only resumed on a large scale from the 1950s. In 1959, tomb Mozuizi 6 in Gansu, dated to the early first century CE, yielded a ritual text written on long wooden slips and already familiar from transmitted literature. From the 1970s onwards, some major manuscript collections were unearthed from tombs, most of them found during construction work and rescued in emergency excavations. The following are just a few of those unearthed well before 2000 (with the assumed sealing dates in brackets followed by the main contents) and excluding those which only yielded written artefacts related to the funeral:

- 1972 Yinqueshan 銀雀山 1 and 2, Shandong (118 and 134 BCE): military theory

- 1972 Mawangdui 馬王堆 3, Hunan (168 BCE): literature, divination, maps

- 1975 Shuihudi 睡虎地 11, Hubei (217 BCE): legal texts

- 1977 Shuanggudui 雙古堆 1, Anhui (165 BCE): literature

- 1983/84 Zhangjiashan 張家山 247, Hubei (186 BCE): legal texts

- 1987 Baoshan 包山 2, Hubei (316 BCE): divination

- 1993 Guodian 郭店 1, Hubei (approx. 300 BCE): literature.

Harvard professor and Confucian Tu Weiming compared the finds from Guodian to the 'Dead Sea Scrolls' and said in an interview in 2001: 'With the discovery of

42 See Guo 2019 for a review of recent Japanese scholarship.

43 See Li L. 2020 on the history of these discoveries.

44 Silk was obviously an expensive writing support and manuscripts made of it were only found in relevant numbers in the tomb Mawangdui 3. Hu (2010) only reports one clumsy attempt to fake silk manuscripts, hence they are not dealt with here. 
these texts, I think you can say that the history of Confucianism itself will have to be rewritten', and 'by implication, the history of ancient Chinese philosophy in general will have to be reconfigured' ${ }^{45}$ Whether or not it is really appropriate, this statement reflects the excitement that the discoveries caused among philosophers and intellectual historians of ancient China. Research on the content of these manuscripts naturally dominated scholarly debates in the East and West. This historiographical attitude still dominates research today.

An estimate from 2011 states a figure of more than 300,000 slips and tablets, including unprovenanced items. ${ }^{46} \mathrm{An}$ archaeological survey from 2014 lists 237 tombs from approximately $500 \mathrm{BCE}$ to approximately $500 \mathrm{CE}$ containing a total of 377 manuscripts, including tomb inventories and fragments. ${ }^{47}$ New finds are made almost every year, some of which are spectacular. Most of the tombs were discovered on the territory of the pre-imperial southern state of Chu, many of them in the vicinity of its former capital near Jingzhou 荊州 in today's Hubei province, such as Hujia caochang 胡家草場 12 (Figs 1a-c).

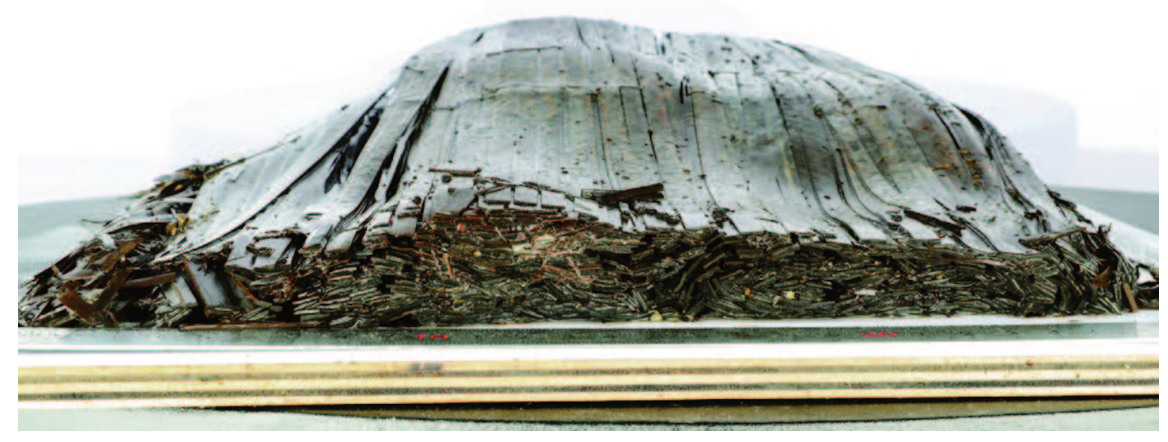

Fig. 1a: Wooden and bamboo slips from a bamboo hamper, tomb Hujia caochang 12, Hubei, closed 163 BCE or later (Jingzhou bowuguan 2020, 19).

45 Shen 2001.

46 Liu G. 2016, 46.

47 [Giele] 2014. 


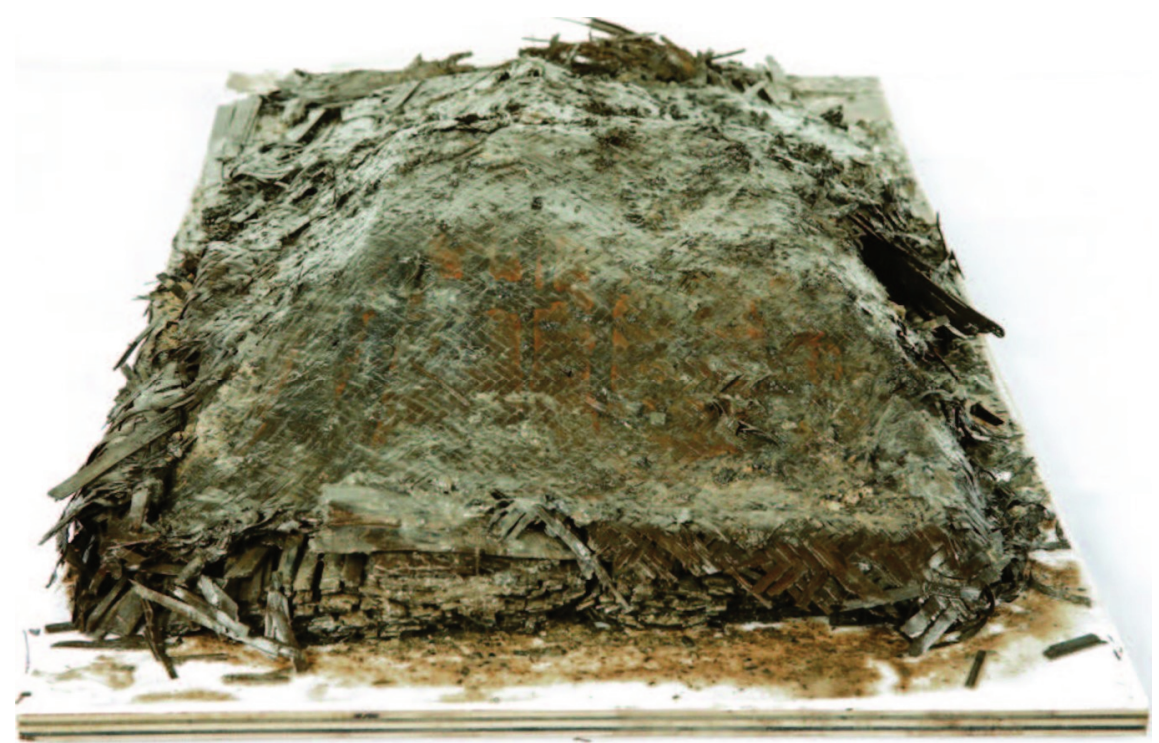

Fig. 1b: still in hamper (Jingzhou bowuguan 2020, 19).

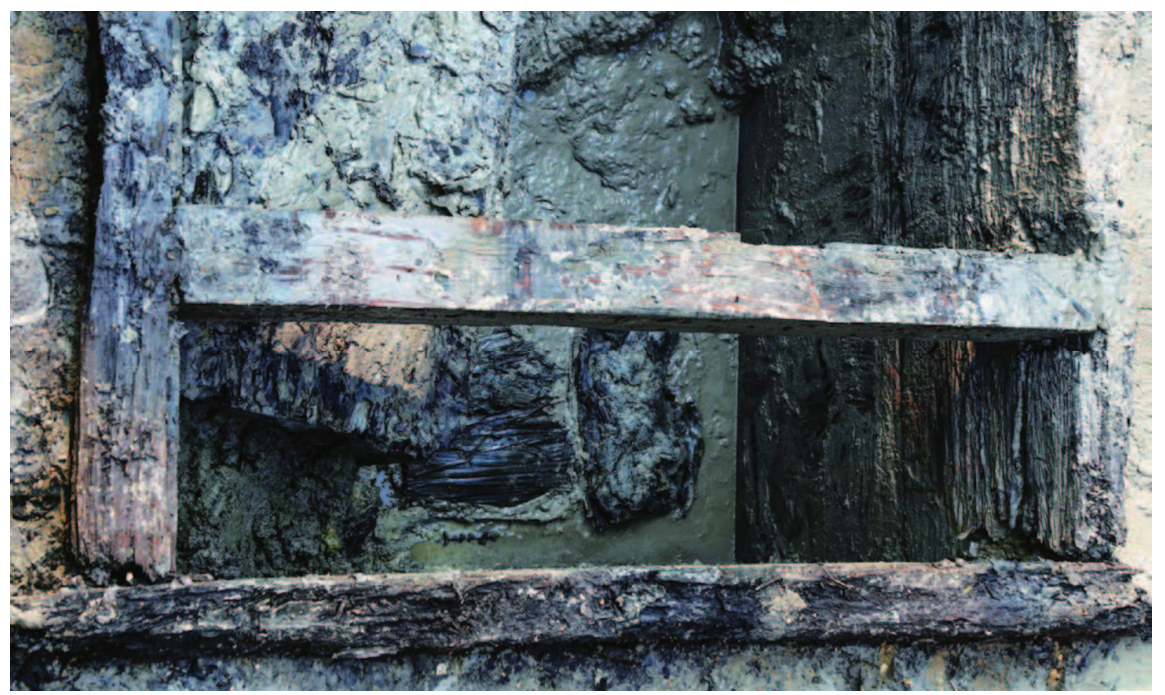

Fig. 1c: in situ (Jingzhou bowuguan 2020, 19).

In addition, hoard finds from wells in Hunan province have yielded huge amounts of discarded documents, the most important ones being Zoumalou 走馬樓 in 1996 
(third century CE) and 2003 (second-first century BCE), Liye 里耶 in 2002 and 2005 (third century BCE) and Tuzishan 兔子山 in 2013 (third BCE -third century CE).

With the exception of some wooden tablets, most of the written artefacts consisted of wooden and bamboo slips. Originally, these slips had been bound together with strings, but due to their state of preservation the overwhelming majority had decayed. Some surviving specimens and remnants of these bindings showed that their number varied from two to five, according to the length of the slips, which ranged from approximately $8 \mathrm{~cm}$ to $80 \mathrm{~cm}$. There was no tradition of codicology to rely on, and real progress has only been made since the turn of the millennium. In the case of bamboo manuscripts, two features have to be mentioned here that were only discovered rather late. Since scholars were eager to decipher the writing on the slips, they neglected their rear side if there was no writing on it. Closer inspection, however, showed that many of the slips were marked with diagonal lines on the verso side (Figs 2 and 3).
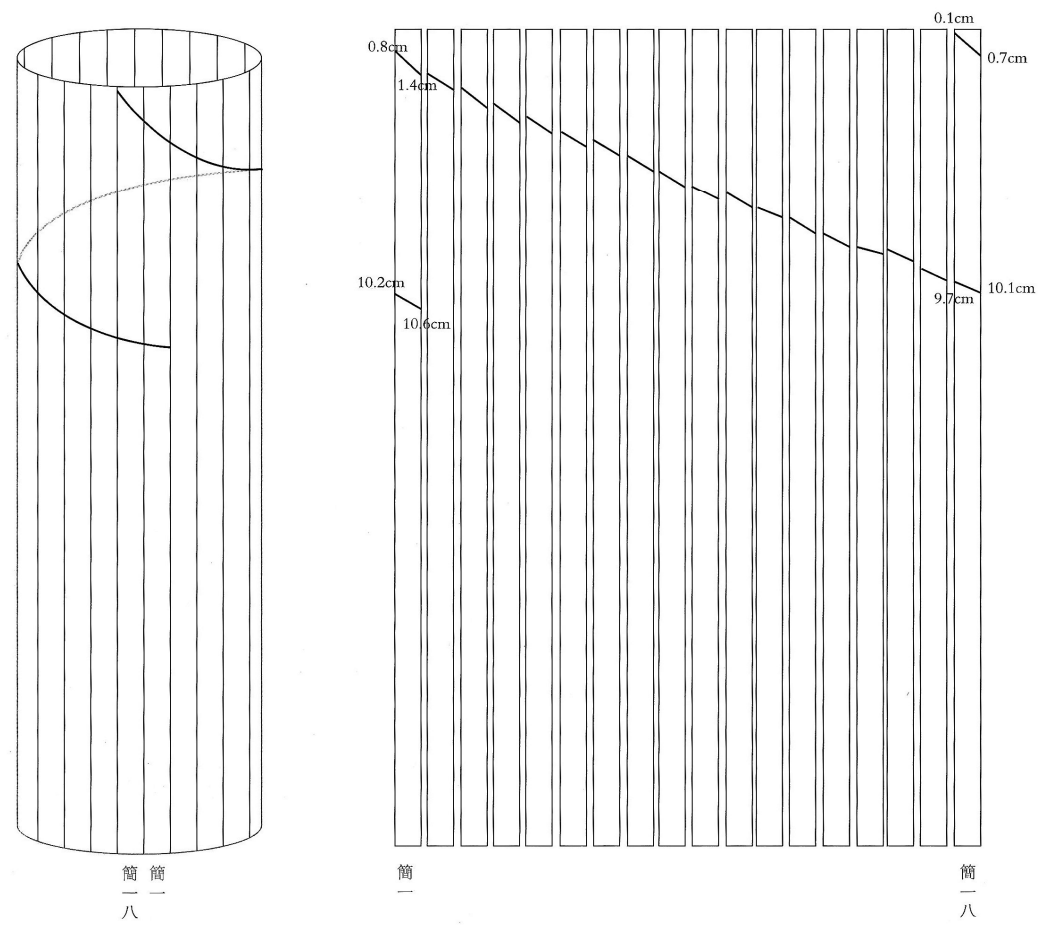

Fig. 2: Spiral-shaped verso line on Peking University Laozi slips 1 to 18 (Staack 2015, 164, Fig. 5; Han Wei 2012, 229). 


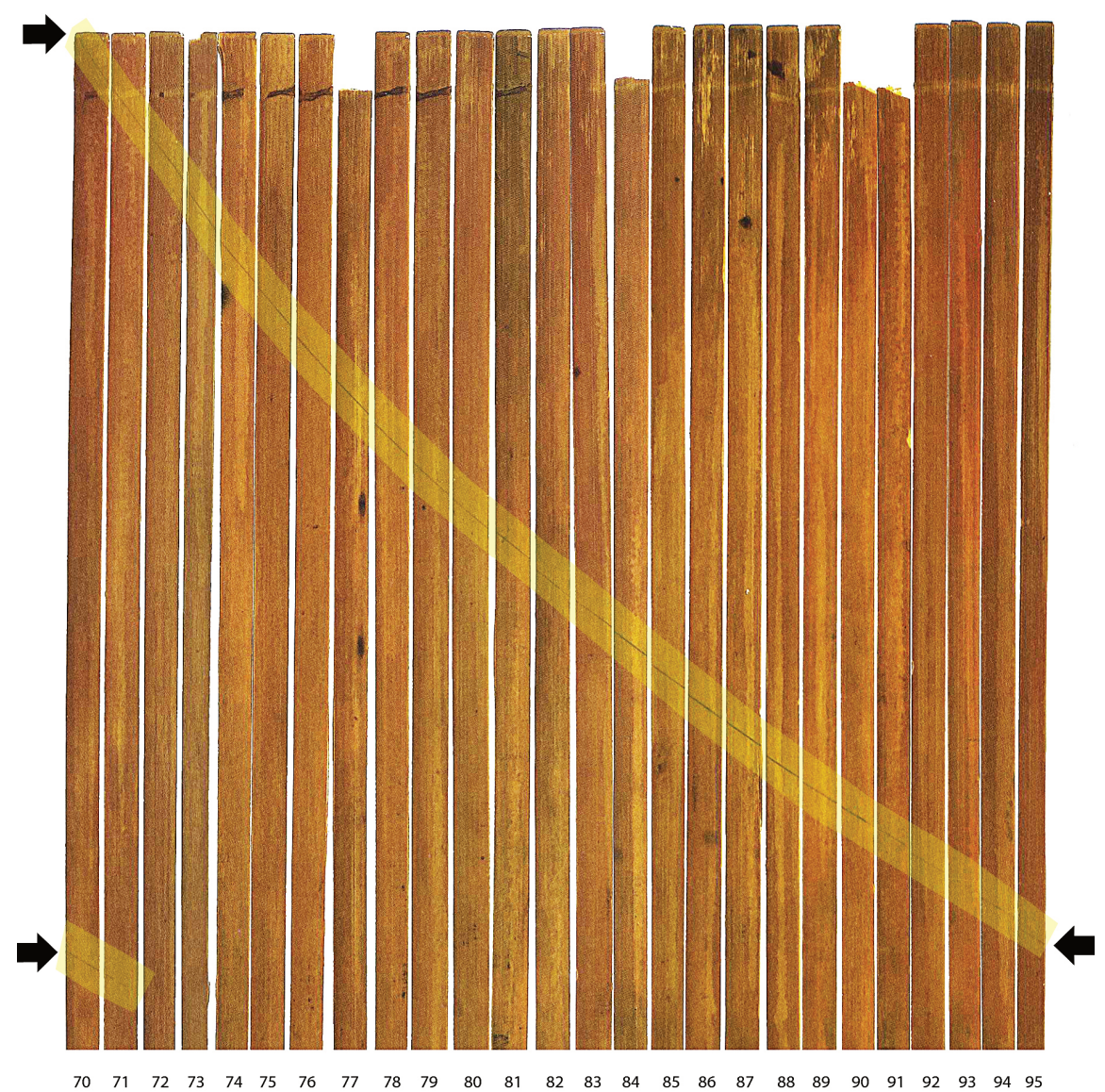

Fig. 3: Tsinghua University Xinian group/set 4 (slips 70 to 95) (Staack 2015, 176, Fig. 9).

The original function of these verso lines is still disputed, but since these lines often match up with the sequence of the writing on the recto side of the slips, they can help researchers to reconstruct codicological units if the bindings have been lost. A second feature one can find is imprints of writing on the rear side of the slips, resulting from them being soaked in water for two thousand years. These verso imprints mirror the writing in the exact position the slips had at the time of their entombment, again helping us to reconstruct the original unit (Fig. 4).48

48 Staack 2015 and 2016. 

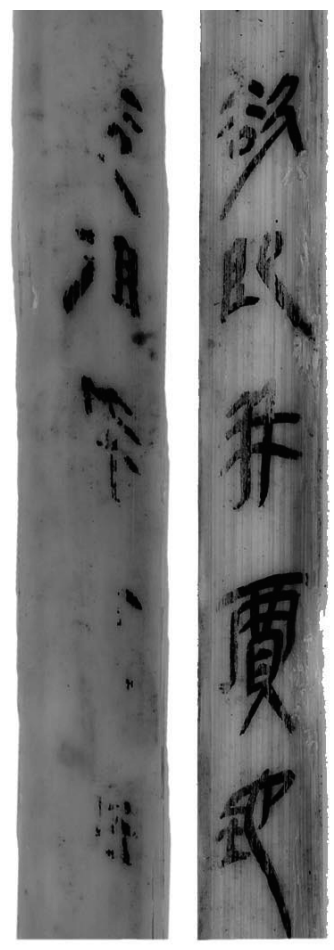

\section{$088 v \cong 075 r$}
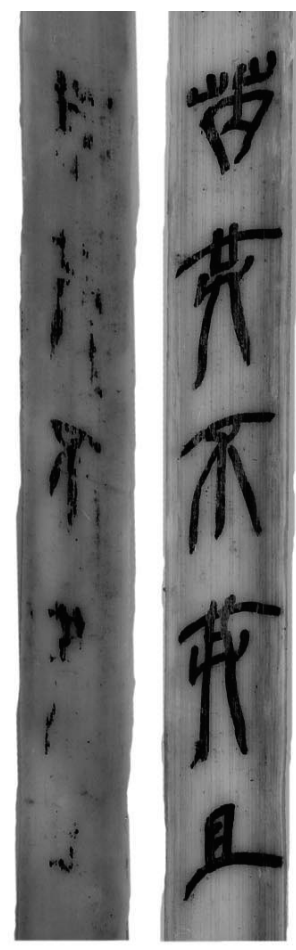

$084 \mathrm{v} \cong 070 \mathrm{r}$
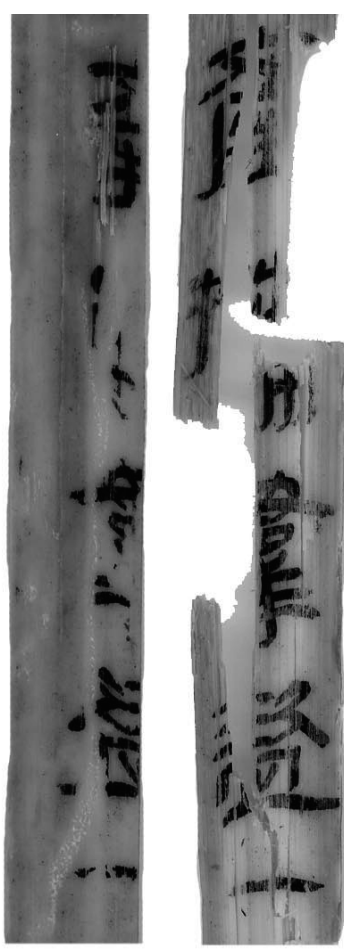

\section{$052 v \cong 036 r$}

Fig. 4: Examples of verso imprints with their respective recto original counterparts (Staack 2017b, 19, Fig. 8).

Depending on their age and provenance, these manuscripts were written either in the Chu script ${ }^{49}$ or in varieties of 'clerical script'. While the latter was already close to the later standard forms and therefore did not pose any fundamental problems in terms of reading, the former was only known from the short texts on the Chu Silk Manuscript. Chinese scholars have dated the manuscripts written in Chu script to the middle or late 'Warring States' period, i.e. the fourth or third century BCE, apparently assuming that its use ended after unification and the

49 By using epigraphic evidence, Haeree Park has tried to show that the 'Chu script' preserved on manuscripts should not be seen as an independent writing system, but as representing the script current from approximately 800 BCE to late pre-imperial times; see Park 2016, 22-23, 243. 
establishment of the Qin empire in 221 BCE. This previously unknown script possessed quite a few unknown features, and new approaches had to be developed to study it. The calligraphic approach mentioned above added some conceptual problems: in calligraphy, standard styles have evolved that supposedly followed a 'genetic' model, developing one after the other. While the Chu script was absent from this traditional taxonomy, 'clerical' is one of its styles. According to the schoolbook history of calligraphy, it gave rise to a 'standard' form, which, in turn, was followed by 'half-cursive' and 'cursive' - much later, namely in the first few centuries CE, just when calligraphy emerged as an art and probably hardly anyone was still familiar with the ancient scripts. Although it was noted in 1991 that cursive and standard styles probably co-existed at any given time, ${ }^{50}$ the genetic model continued to play a role in dating and interpreting the evidence provided by manuscripts.

While the sites mentioned above were scientifically excavated, at least in principle, looted artefacts from tomb robberies started appearing on antique markets in China and Hong Kong in the 1990s.

\subsection{Tomb robbing}

The looting of tombs must have been a widespread phenomenon in ancient times. When noble people were buried, their tombs were sumptuously furnished with precious objects, which made them attractive targets for thieves and vandals. An 'exemplary' criminal case from the late third century BCE dealt with tomb looting. ${ }^{51}$ An anecdotal source reports that Liu Quji 劉去疾 (d.70 BCE), King of Guangchuan 廣川王, practised it 'as sport', opening all the tombs in his fief. ${ }^{52}$ In $279 \mathrm{CE}$, a robber who had looted a royal tomb from the pre-imperial state of Wei 魏 in Ji 汲 was caught with bamboo manuscripts containing ancient writing. ${ }^{53}$ Converting funeral sites into farmland and robbing tombs was done continuously in the past and is still done today, in fact, despite it being a punishable offence..$^{54}$

50 Friedrich 1996, 109.

51 A case of tomb robbery is among the 'exemplary cases' in the Yuelu Academy collection; see Lau/Staack 2016, 129-144.

52 Xijing zaji 西京雜記 6; see Kolb 2006, 436.

53 See Liu G. 2016, 17-25.

54 The first extant legal code from 653 contains stipulations on both activities; see Tanglü shuyi 唐律疏議 13, article 168, and 19, article 277; for an English translation see Johnson 1997, 142-143 and 286-288. 
Following the upsurge of the art and antique market, the looting of tombs intensified in the 1990s in a bid to satisfy the ever-growing demand for such artefacts among collectors. Ni Fangliu 倪方六, a leading Chinese expert on tomb robbing, estimated in 2015 'there may be as many as 100,000 full-time tomb raiders in the country'. Local peasants and migrant workers participate in the trade. Some families have even specialised in looting tombs, doing so for generations in some cases. On top of that, young people have been attracted to the activity after reading or watching the Chinese version of Tomb Raider, Grave Robbers' Chronicles, which first appeared in print in 2007 and has been successfully merchandised in various media since then. ${ }^{55}$ In 2015, 175 alleged tomb robbers were arrested in an operation involving around 1,000 police from six provinces. The South China Morning Post reported about it:

Investigators found a well-oiled network, with different tasks from site excavation to contacting traders on the black market divided between 10 teams.

To hide its origins, an illegally excavated artefact will usually change hands at least three times - going from looters at a remote rural site through a network of dealers to a regional hub before reaching a port to be shipped overseas, several antique dealers told the Post.

Once the smuggled artefact reaches an international trading centre like Hong Kong, dealers declare it as a Chinese artefact secured overseas that can then be legally traded in the mainland. ${ }^{56}$

Not only works of art were among the artefacts offered in Hong Kong, but manuscripts were as well.

\subsection{Unprovenanced ancient manuscripts: looting and faking}

The first major ancient-manuscript deal that a Hong Kong antique dealer struck was with the Shanghai Museum, which first bought 1,200 slips in Chu script in May 1994 and then another 500 slips a few months later. And as $\mathrm{Hu}$ Pingsheng reported in 2010, negotiations to purchase three caches of approximately 2,000 slips each for Chinese universities had been underway since 2006. All these deals were finalised in little more than a year, from late 2007 to early 2009: a corpus with legal stipulations and practical texts from the late third century BCE went to the Yuelu Academy of Hunan University, a collection mainly containing literary

55 The starting point is the looting of the tomb yielding the Chu Silk Manuscript and its 'fraudulent removal' by an American: [Xu] 2007, 6; also see Ge 2015.

56 Ge 2015. 
texts in Chu script from pre-imperial times was acquired by Tsinghua University, and the third cache, again mainly with literary texts, but this time from Han times (the second century BCE), ended up at Peking University. ${ }^{57}$ Research institutes were established to study these manuscripts, and it became a matter of prestige to own some - in fact, Prime Minister Wen Jiabao 溫家寶 visited Tsinghua University for a personal inspection of the slips in $2009 .{ }^{58}$ Accordingly, further institutions of higher education followed: Zhejiang University in 2009 (slips from abroad), Wuhan University in 2011 (from Hong Kong), and Anhui University in 2015 (from abroad). Funds came from alumni or other 'friends of the University' and foundations whose identity was not always disclosed. ${ }^{59}$

Forgeries of ancient manuscripts began to appear on the market in the 1990s. $\mathrm{Hu}$ Pingsheng 胡平生, one of China's senior experts in ancient manuscripts, summed up his own experience with forgeries in $2010 .{ }^{60}$ He reported thirteen cases in detail that had occurred since 1995 and said that he and his colleagues had been shown fakes hundreds of times in the last twelve years or so. Li Xueqin 李學勤 (1933-2019), the famous historian from Tsinghua University, is said to have seen a corpus of 5,000 slips at a friend's - all of which were fakes. At first the victims of this type of fraud were mainly private collectors in East Asian countries first of all, the objects often being channelled through Hong Kong, but increasingly through the Beijing Antique Market (Panjiayuan 潘家園) as well later on. Fakes were also offered to universities, not just private buyers. In some cases, the forgers just produced clumsy imitations, but in others they imitated the scribal hands found in authentic manuscripts, using content from received literature. In 1996, a manuscript with 82 chapters supposedly from Han times with a text by the ancient military theoretician Sun Wu was the object of heated debates on its authenticity, involving the media and scholars on both sides. The matter finally ended up in court. The experts immediately knew that it was a fake since the first reports had already mentioned that the three units were bound together with strings running through holes and that it was written with lacquer - which genuine manuscripts never contained. ${ }^{61}$ The most disturbing instances of forgery,

57 For reports on the acquisitions, see Hu 2010, 104-105; Liu G. 2016, 51-54 (Tsinghua University) and Foster 2017, 181-184 (Peking University); Peking University later purchased a corpus of manuscripts from Qin times, but this will not be dealt with here.

58 Liu G. 2016, 87.

59 If at all, information about this is usually provided in the first public announcements and publications of the slips.

60 See Foster 2017, 173-177 as well.

$61 \mathrm{Hu} 2010$, 89-90. According to $\mathrm{Hu}$, the person having fabricated it including its provenance was well-connected, and in 2004 he started a new attempt to advertise it, see Li R. 2004. 
however, were those in which authentic slips were mixed with fake ones. 'Some Hong Kong universities' received a large number of slips in the 1990s, most of which turned out to be fakes and were returned to the dealer. In other cases, hearsay had it that corpora acquired by Chinese institutions at the end of the 1990s also contained fake slips. ${ }^{62}$

$\mathrm{Hu}$ supposes that the forgeries may have begun with the replicas and copies produced for museums to sell. ${ }^{63}$ To do this, some local museums in Hubei had used slips made from original wooden boards unearthed from tombs. These objects would obviously withstand radiocarbon testing because they were authentic. ${ }^{64}$ Finally, Hu asserts that the forgers have made a 'leap forward' since 2008: they not only refined the techniques they used to age materials, but they also greatly improved their ability to faithfully reproduce characters of the Chu script and of the Qin and Han clerical scripts. Some fake slips he had recently seen in Hong Kong were 'of a deep black colour, the writing neatly executed, genuine-looking and, with the exception of a few strokes, hard to distinguish [from original ones], so if one is not really concentrating, one could easily misjudge them'. ${ }^{65}$ This advance naturally made it much harder to identify forgeries.

\subsection{Identifying fakes}

In his article, $\mathrm{Hu}$ goes on to propose four 'principles' for identifying fakes. While the last one - provenance - is self-evident, the first three warrant a closer look, especially since mutatis mutandis, they remain the point of departure for later authors:

1. 'Characters, style and textual coherence' (wenzi, wenfa yu wenli 文字、文法 與文理): the 'spirit' ( $q$ i 氣, lit. 'breath') of the Ancients is difficult to fake; palaeographers can even read the difficult Chu script, but forgers are unable to produce fine works in it; a script style changes over time - even Han clerical changed [which was basically known before] - and if a forger were able

$62 \mathrm{Hu}$ 2010, 76-84; for the slips of the Chinese University of Hong Kong see Liu G. 2016, 46 and Chen 2001.

63 See Cécile Michel's contribution to this volume regarding the similar case of the Ready Brothers at the British Museum.

$64 \mathrm{Hu} 2010,100$.

$65 \mathrm{Hu}$ 2010, 101: 黑色濃黑, 書體工整, 逼真, 除了個別字畫外, 很難判別, 稍不留神便會 “走眼” . This might or might not refer to the Zhejiang University slips which had also appeared in 2008; see Cao 2011, Qianyan 前言, 1 . 
to grasp the rules of script development, he would not need to be a forger any more, but could become a scholar. The same holds true for the content.

2. 'Material and form' (zhicai yu xingzhi 質材與形制): in the North-west, wood is mostly used as a writing support: salt cedar (hongliu 紅柳, Tamarix ramosissima), qianersong 杆兒松 (Picea neovetchii mast.), ${ }^{66}$ Euphrates poplar (huyang 胡楊, Populus euphraticus), bamboo (but only for canonical books and important documents). If unearthed and kept away from light, wooden slips can keep their light colour for a long time, but they will darken soon after being exposed to light. Forgers either use fresh wood whose colour is too light or they age it, with the result that the colouring is too homogenous. In the South, slips have been soaked in water for two thousand years, resulting in the destruction of their cells, meaning that they basically resemble spaghetti, which has been impossible to fake so far; forgers prefer wood because it is easier to deal with, but they make mistakes regarding the dimensions of the slips.

3. 'Calligraphy and calligraphic style' (shufa yu shufeng 書法與書風): forgers exaggerate certain features of Han clerical, but even in good fakes the 'calligraphers cannot hide their superficial and ordinary spirit'. ${ }^{67}$

This is not an innocent sequence, but clearly signifies the primacy of textual study based on calligraphy. While the second of these principles apparently refers to codicology, the first and the third overlap. The first one seems to include philology and palaeography, but we can already see clear references to the art of writing here, and the third one deals explicitly with calligraphy. Hu follows an approach developed by epigraphy, combining the calligraphic and historiographical attitudes. ${ }^{68}$ We should bear in mind here that in colloquial usage, 'calligraphy' is used for the quality of every type of handwriting, and that the word 'writing' is not only ambiguous in Chinese, as it may stand for composing a text as well as writing it down. In consequence, then, authentic manuscripts retain traces of the spirit of the Ancients. Only scholars can recognise this particular quality, and forgers are never able to reproduce this kind of spirit. If they could, they might as well become scholars - which is obviously thought to

66 Written as 任兒松 in the article; Hu probably quoted Xia Nai's survey of some newly discovered Han slips from Dunhuang, see Xia 1948, 260. Thanks to Xiaomeng He who provided this reference.

$67 \mathrm{Hu}$ 2010, 98-101; Foster 2017, 176 has translated the first three 'principles' as 'textual errors; physical constitution of the manuscript; calligraphy'.

68 He more than once invokes the epigrapher Chen Jieqi 陳介祺 (1813-1884). 
be a desirable status. $\mathrm{Hu}$ does not mention the other possibility, though - that a scholar might become a forger.

In 2009, Jiang Guanghui 姜廣輝 proposed textual criticism (wenxian kaozheng 文獻考證) and intellectual history as a remedy against forgeries since material analysis (i.e. radiocarbon dating) and the assessments of specialists based on experience (i.e. palaeography) were not reliable. He did not rule out the possibility that a 'high-calibre' (gaoji 高級) forger might be able to produce a fake that was so good it could deceive natural scientists and palaeographers. ${ }^{69}$ Jiang's article was a response to the first publication of one of the texts contained in the unprovenanced manuscripts that Tsinghua University had acquired, which was authored by Li Xueqin; Jiang doubted it was genuine. Just like the article by Li and further debates in the following years, Jiang's critique appeared in the Guangming ribao, thus airing this scholarly dispute in public.

In 2012, Xing Wen 邢文 published his arguments disputing the authenticity of one of the Zhejiang University manuscripts called Zuo zhuan 左傳. A student of Li Xueqin's and a professor of Asian societies, cultures, and languages at Dartmouth College, he first discussed codicological aspects, then the content and finally the calligraphy: 'the style of writing of the Zhejiang University slips is coarse-looking and very inferior, the structure of the characters confused and faulty, they are vulgar and without rule or any sense of antiquity - they are definitely not traces of writing from the Warring States', he declared. ${ }^{70}$ Since many scholars apparently shared this assessment, there was a silent consensus about them being fakes, in spite of radiocarbon dating and ink analysis supposedly confirming their non-modern production. ${ }^{71}$

A similar critique followed in 2016, this time directed at the Laozi owned by Peking University. This attack generated heated debates, however, which were additionally fired by the lack of radiocarbon dating and by rudimentary material analyses. ${ }^{72}$ Xing mainly based his arguments on features of the verso lines and of characters written on broken slips. In turn, these allegations were critically analysed and refuted by other scholars who had independently arrived at the same conclusion. One of them remarked that his arguments against Xing 'do of course not prove that the Peking University Laozi is not a forgery. They can merely serve to disprove or at least put into perspective the arguments advanced to claim that

69 See Foster 2017, 177-178.

70 Xing 2012: 浙大藏簡筆法粗婳拙略, 結字混亂錯謬, 俗而無法, 了無古意, 決非戰國書迹.

71 Foster 2017, 178-180.

72 Foster 2017, 183-184; radiocarbon dates were provided for the cache of Qin manuscripts later acquired by Peking University. 
it is a forgery'. ${ }^{73}$ Since the text of the Laozi was well-known, and Xing obviously did not detect any problems here, his analysis concentrated on codicological and palaeographical features.

In the same year, 2016, Ulrich Lau and Thies Staack used the occurrence of verso lines and verso imprints on slips to refute the forgery of unprovenanced manuscripts kept at the Yuelu Academy. Since their codicological relevance was first discussed in publications in 2011 and 2013, forgers could not have known about this feature before, even though the verso lines were already briefly mentioned in a publication from 1991. In addition, the texts contained some formerly unknown linguistic features that were only found later in scientifically excavated manuscripts and thus confirmed the authenticity of the artefact. ${ }^{74}$

A recent attempt by Christopher J. Foster to establish a 'method for positively authenticating purchased bamboo manuscripts' combines Hu's approach summarising the first decades of research with some new ideas 'appealing to more objective criteria' by integrating the codicological argument and generalising it:

\begin{abstract}
We must identify within the newly purchased manuscripts completely novel features, ideally irregularities that are unanticipated by the current state of knowledge in the field. Such features may include aspects of the manuscript's physical constitution (from raw materials used, to how the strips are fashioned and bound), calligraphy (the type or style of brushwork, unusual character forms), and content (vocabulary usage, odd grammar, surprising facts that go against accepted history, etc.) ... If these novel features can then be confirmed by archaeologically excavated data first available or fully appreciated only after the purchased artefact was secured, then we may be convinced of its authenticity. ${ }^{75}$
\end{abstract}

As the author states, this method was developed while studying a manuscript from the Peking University collection. He convincingly showed that it worked just as well as for the manuscript studied by Lau and Staack, in his case mostly relying on texts only published after the acquisition of the Peking manuscript. As much as his methodological optimism is to be applauded, it should be kept in mind that each manuscript, whether genuine or not, is a unique artefact with its own history and might thus require individual treatment. Moreover, it is clear that this 'method' will no longer work for artefacts surfacing once the 'novel features' have been publicised.

One of the latest additions to the debate is an article by Mai Di 麥笛, published at the end of 2019, which draws on recent research. Vehemently defending

73 Staack 2017a, 15; also see Foster 2017, 185-215.

74 Lau/Staack 2016, 12-13.

75 Foster 2017, 215-216. 
the authenticity of the Tsinghua University and Anhui University bamboo manuscripts, the author builds on the 'principles' of Hu Pingsheng and develops five criteria for determining a manuscript's authenticity:

1. Judgement based on direct inspection of the writing support (part of Hu's second principle, codicology).

2. Scientific analysis of the support (absent from Hu's list, including radiocarbon dating and comparison with scientifically excavated bamboo slips by non-destructive methods such as infrared spectroscopy and measurement of crystallisation degree and water content; no ink analyses because of the difficulty in taking samples).

3. Form of the support (another part of Hu's second principle, codicology).

4. Structure and style of the characters (part of Hu's first principle and his third principle, palaeography).

5. Elements of content (another part of Hu's first principle) ${ }^{76}$

In conclusion, then, no forger would be able to cope with even one of the five criteria, let alone all of them. While material features have become more prominent and the language less 'calligraphic', Mai leaves no doubt that criterion no. 4 is the most important one. His rebuttal to 'sceptics' only addressing the content obviously targets scholars like Jiang Guanghui who based their doubts about certain texts in unprovenanced manuscripts on textual criticism. The harsh language and the advice to leave these matters to the experts make it clear that there was more at stake here than just an academic dispute.

Li Xueqin was not just $a$ historian; he was one of the most influential historians of his generation - a member of the Chinese Academy of Social Sciences close to the State Council, an expert in many fields and the mastermind behind the 'XiaShang-Zhou Chronology Project' (1996-2000), which established an absolute chronology of Chinese history going back to the late third millennium BCE. This prestigious undertaking involved 200 scholars and produced results that were completely rejected outside China and politely ignored by numerous scholars in the country as well. Using highly disputed methods, it pushed the origins of the Chinese state back a further thousand years to the late third millennium BCE. ${ }^{77}$

76 Mai 2019.

77 See Li X. 2002 for an English presentation of the project. For devastating critiques by two of the foremost Western scholars in the field, see Nivison 2002 and Shaughnessy 2008 and 2011. The project is said to have been inspired by the rich archaeological and textual evidence of Egypt's long history witnessed by Chinese archaeologists in the early 1990s; see Storozum/Li 2020, 16. 
Since the Prime Minister had visited Tsinghua University in 2009 to inspect the bamboo slips and looked into the project at the time, it would have been more than embarrassing to admit that there were still doubts about the authenticity of the manuscripts. Furthermore, one of Li's projects was to revise the prevalent critical attitude towards traditional views of the prehistory and early history of China and to restore the credibility of ancient sources.

The texts in the Tsinghua manuscripts obviously supplied arguments in favour of this approach: among other things, they contained one of the lost chapters of the Book of Documents and the 'last words of King Wen', as Li called it. King Wen was the first king of the Western Zhou (1050/1045-771 BCE) and later became the ideal representative of legitimate rule in the Confucian tradition. In the text, the notion of 'the mean' (zhong 中) played an important role, which was emphasised by Li in order to show that this central Confucian concept could indeed be traced back to the early Zhou. This nicely matched the slogan of a 'harmonious society' with its 'Confucian' elements advocated by General Secretary $\mathrm{Hu}$ Jintao 胡錦濤 and Prime Minister Wen Jiabao, the same man who had looked into the Tsinghua project in 2009. In his critique from the same year, Jiang characterised the text's notion of the mean as anachronistic and constructed with ideas only developed from the eleventh century CE onwards. The question of authenticity clearly involved a fundamental disagreement on the history and historiography of early China and the role Confucianism played in it.

\section{Some observations on method}

Science and scholarship can never prove beyond doubt that an object is authentic; in some cases, they may be able to show it is not, but in most, they can only assemble evidence making either option more or less plausible. ${ }^{78}$ Just as in other historical enquiries, a consensus among the experts defines what is to be accepted - until better arguments are put forward in favour of the weaker position or another point. ${ }^{79}$ The following observations critically examine criteria and arguments for authenticating originals and identifying fakes in order to uncover underlying patterns.

78 See Craddock 2016, 2-5 on the limitations of material analysis and its interdependence with art history. Also see Oliver Hahn and Ira Rabin's contribution in this volume and the introduction in Whitfield 2002 regarding the Dunhuang manuscripts.

79 Koselleck 1977; see Jost Gippert's article in this volume for a case study. 


\subsection{Material}

Almost ${ }^{80}$ all of the unprovenanced manuscripts discussed so far consist of bamboo slips, most of which are in scroll form..$^{81}$ In some cases, their writing support has been identified as belonging to the genus of hard bamboo (gangzhu 剛竹, Phyllostachys), while in others the reports lack information. No analysis of the species seems to have been made yet. ${ }^{82}$ One of Hu's criteria for discerning fakes was the condition of the bamboo slips at the time of acquisition. Genuine ones will have been soaked in water for two thousand years, making them look like cooked spaghetti, which is a condition no forger is able to fake. Why not? ${ }^{83}$ One would have to prove this, which is impossible, of course, and there may be methods which yield similar results. ${ }^{84} \mathrm{~A}$ tacit understanding seems to exist that samples of unprovenanced bamboo slips should not be subjected to destructive testing such as fibre analysis or radiocarbon analysis. If slips are tested at all, then only one or two of them, usually just fragments without any writing on them. Sometimes even bamboo objects other than slips are analysed..$^{85}$ Sampling methods and procedures which are decisive for controllability are hardly ever mentioned. This means that a forger would just need to insert one or two blank slips or fragments which are often found in ancient tombs into a bundle of fakes to scientifically prove their ancient origin. ${ }^{86}$

A comparative method is employed to determine the relative age of bamboo slips: properties of one or two of the unprovenanced slips are compared to those of fresh bamboo and to specimens from scientifically excavated sites. For two tests of the slips held by the Yuelu Academy and Peking University respectively, one slip unearthed near Jingzhou was analysed (not a slip, but an excavated

80 I am grateful to Oliver Hahn for commenting on a draft of this sub-chapter.

81 One of the few exceptions is a codicological unit consisting of approx. 25 wooden slips in the Yuelu corpus; see Lau/Staack 2016, 18.

82 See Staack 2015, 165; see Huet al. 2011 on the Han slips acquired by Peking University.

83 Craddock 2016, vii: 'This book is intended as a comprehensive guide to the technical and scientific study of the authenticity of a wide range of antiquities and artistic creations'; it does not mention bamboo, however.

84 Apparently, no experimental archaeology has been done on bamboo slips that might help us find out more about the splintering of slips, which has been observed in quite a few cases. Jörg Fromm and Silke Lautner have recently conducted tests showing that maceration of Phyllostachys produces results similar to the condition of bamboo slips described by Chinese scholars. Their results will be published shortly.

85 Foster 2017, 180 and 183-184.

86 In Baoshan 2, for example, 170 of the 448 slips did not have any writing on them; see Hubei sheng Jing Sha tielu kaogudui 1991, 3. 
'piece of bamboo' was used for the second test) and one from Zoumalou, both of which are sites archaeologically dated to Han times. The fibre structure and water content of the fresh bamboo were completely different to the other ones, which closely resembled each other, thus suggesting a similar date. ${ }^{87}$

In most cases, documentation of the condition of slips is cursory at best, but a quick look will reveal some differences: while the Yuelu Academy slips were received in plastic bags containing eight bundles at least partially maintaining the state they had when they were first unearthed ${ }^{88}$ the Tsinghua University slips 'were bound with plastic wrap, with some of the strips matted on fresh pieces of bamboo, and shut with tape wound around both ends'. Judging by a picture of them, these wraps came in more or less identical batches consisting of two or three dozen slips, which probably no longer looked the way they did at the time of looting. ${ }^{89}$ Dissolving the original codicological units would obviously allow them to be manipulated, such as by mixing fake slips among them. In addition, there is always the possibility that one corpus contains slips from more than one spot, leading to different dating. ${ }^{90}$

Furthermore, in most cases where tests have been conducted, only the results have been published, not the reports leading to them, as the following list shows (the initial number of slips includes fragments and is often substantially reduced when fragments are joined after closer examination):

- Shanghai Museum (approx. 2,000 slips): radiocarbon dating (third century BCE), report repeatedly announced, but still not published..$^{91}$

- Yuelu Academy (approx. 2,200 slips): comparison of properties of the slips with those of scientifically excavated Han slips, report published, ${ }^{92}$ but no radiocarbon dating.

87 Fang/Tong 2010; Hu et al. 2011; also see Cao 2011, 192-193 and Fang et al. 2012 on the ageing of bamboo.

88 See the report in Chen 2009 and the images in Zhu/Chen 2010, 204-220.

89 Liu G. 2016, 55-56.

90 See the statement by Chen Songchang 陳松長 in Beijing daxue chutu wenxian yanjiusuo 2009, 9-10.

91 Ma Ch. 2001, Qianyan 前言, 2: ‘late Warring States' (third century BCE); also see Foster 2017, 172, n. 17.

92 Fang/Tong 2010 compared slips from the Yuelu Academy with Han slips from Jingzhou and Zoumalou and found them to be very similar, unlike fresh ones. 
- Tsinghua University (approx. 2,400 slips): radiocarbon dating of one blank fragment (303+/-30 BCE), analysis of water content (400\%); no reports published. ${ }^{93}$

- Peking University (approx. 3,300 Han slips): analyses of blank bamboo fragments, red pigments and traces of bindings, report published; no radiocarbon dating. ${ }^{94}$

- Zhejiang University (approx. 160 slips): radiocarbon dating, fibre analysis, depth of ink penetration and comparative infrared spectroscopy, all reports published (approx. 340 BCE)..$^{95}$

- Wuhan University (approx. 110 slips): not published. ${ }^{96}$

- Anhui University (no number of slips available): radiocarbon dating ('approximately 2,280 years before now'), no report published. ${ }^{97}$

For preservation and better readability, the slips are usually subjected to chemical treatment that obliterates all possible trace elements that might help in characterising ink and other pigments. Although the routines vary from place to place, a report on the Tsinghua slips is revealing in this regard. Besides being used to kill off mildew, chemical agents are also employed for 'washing' the slips:

Before photographing a bamboo strip, we needed to decolorize it, that is to say, remove any staining from the strips and return them to their natural coloring. Each bamboo strip has its own unique shading, and because the coloring is not uniform, it is often difficult to obtain ideal results from the photography. Decolorization helps bring the strips back to what was approximately their original appearance. Having gone through this chemical treatment, most of the strips turn beige, which is basically the original color for the bamboo, and the writing on them becomes even clearer, producing superior results during the shoot. ${ }^{98}$

As a rule, the scroll bindings did not survive, but traces of them were often found on the slips. The results of analyses have been published in a few cases; usually it is a variety of ramie (genus Boehmeria, ningma 艼麻). ${ }^{99}$

Compared to international standards, this data is meagre and does not prove anything. On the other hand, scholars do not usually regard it as being of decisive

93 Just a few lines in Li X. 2010, Qianyan 前言, 3; also see Li/Liu 2010, 9 and Liu G. 2016, 79-80. The water content of the slips is said to have been $400 \%$.

$94 \mathrm{Hu}$ et al. 2011.

95 Cao 2011, 191-196.

96 Xia Jing 2013, dated to approx. 350 BCE.

97 Huang/Xu 2019, Qianyan 前言, 1.

98 Liu G. 2016, 80; see 60 for the mildew treatment.

99 E.g. Hu et al. 2011. 
importance: in 2010, the preface to the first volume of the publication of the Tsinghua slips mentions that after authentication by scholars in 2008, the slips were subjected to radiocarbon testing 'in order to verify the scholars' assessment' ${ }^{100}$ In addition, it said the high water content in the slips, which is impossible to fake, was only 'collateral evidence' (pangzheng 旁證). ${ }^{101}$ The wording leaves no doubt that judgement is first pronounced by the scholars and scientific data is only collected in order to corroborate their assessment. ${ }^{102}$

When 'authenticating' the Peking University slips in 2009, Peng Hao 彭浩 asked why the cinnabar used for writing the titles on one of the Peking University manuscripts looked so fresh and had not come off, because there was no solvent in pre-imperial times. He recommended analysing this material and, being an archaeologist, expressed his hope that

together with the publication of the slips also reports relevant to authentication will be published. I believe that many tests should be undertaken, but today there is no opportunity to explain. The data on the Shanghai Museum slips from two accelerators reported earlier were extremely divergent, making it difficult to pass judgement, and it was never published how the samples were taken and how they were tested. That rumours about fakes among the Shanghai Museum slips have never stopped, is closely related to the fact that those data were never published..$^{103}$

The Zhejiang University slips were tested most comprehensively according to standards prevalent in China, with the results confirming their age, and all the reports were published - but these slips are generally accepted as forgeries. ${ }^{104}$

\subsection{Form}

Scrolls made of wooden or bamboo slips, sometimes hundreds of them, were a book form that went out of use for much more than a thousand years and which is only known to us from literary sources. Accordingly, their study only

100 Li X. 2010, Qianyan 前言, 3: 為了印證學者們關于竹簡時代的鑒定論斷.

101 Li X. 2010, Qianyan 前言, 3.

102 Also see Liu G. 2016, 70-72 on the authentication of the Tsinghua slips. This is basically a clearance certificate by famous scholars without any discussion of possible problems. Since Liu G. 2016 is the English version of a doctoral dissertation supervised by Li Xueqin, one may safely assume that it represents the 'official' story; see Li/Liu 2010, too. Allan 2015, 68-70 quotes articles by Hu Pingsheng and declares the slips to be authentic.

103 Peng's statement was one of the few not only congratulating Tsinghua University and Li Xueqin; see Beijing daxue chutu wenxian yanjiusuo 2009, 9.

104 See Foster 2017, 180, n. 47. 
commenced after the first discoveries were made in the early twentieth century. While most of the evidence initially consisted of wooden slips from the Northwestern deserts, more recent discoveries of bamboo manuscripts from soaked tombs and wells in the South confronted scholars with new problems. Only recently has it become clear that despite the apparent similarity of wooden and bamboo scrolls, the production of the latter differs considerably from the former due to the practice of using slips from the same culm segment as a codicological sub-unit. ${ }^{105}$

It has become a commonplace to use the occurrence of verso lines as an argument for the authenticity of bamboo manuscripts if they were acquired before the publication of the seminal article in 2011. As has been remarked more than once, the 1991 report on the excavation of tomb Baoshan 2 already mentioned them, albeit without any reference to their relevance. This argument is persuasive, but it still leaves room for doubt. The short paragraph on those lines does contain all the relevant information:

On the rear side of a few bamboo slips there were diagonal lines drawn with a knife or brush, based on which some of the neighbouring slips could be joined according to their order ( $k e$ juci yici xiangjie 可據此依次相接), but not others. These two types of lines were possibly a kind of mark (jihao 記號) applied before binding the slips. ${ }^{106}$

Twenty years is a long time. What if someone realised this feature - a mark of genuine manuscripts from Chu before its 'official' recognition - and the 'discovery' of the relevance of these lines had been made more than once? It is noteworthy that Sun Peiyang 孫沛陽, the undergraduate student who first published it in 2011, claims to have already noticed this phenomenon 'a few years earlier' while working on one of the Shanghai Museum manuscripts, and articles discussing this feature had possibly even appeared before Sun's did. ${ }^{107}$ The presence of these lines in many more corpora, whether provenanced or not, proved that this feature was authentic; it did not, however, prove that every slip was marked in this way. Some statistics would be welcome here in order to assess the presence or absence of these lines properly. How many scientifically excavated objects do they appear on, for example? Is their presence related to any other features, either contentrelated or material? How should we deal with cases in which a codicological reconstruction does not match the textual reconstruction? Since the verso of the

105 See Staack 2016 for an overview of the history of attempts to reconstruct the original units. 106 Hubei sheng Jing Sha tielu kaogudui 1991, 4; see the slightly different translation in Foster 2017, 218.

107 Foster 2017, 218; Sun 2011, 49. 
bamboo manuscripts was long neglected if there was no writing on it, there are still 'authentic' artefacts lacking documentation of the verso today. ${ }^{108}$

The notches used to fix the binding strings are another feature we known of from scientifically unearthed manuscripts. The 1991 report on Baoshan 2 described them in detail, mentioning that most of the slips had them, but a few of them did not. ${ }^{109}$ Again, statistics from the whole corpus of archaeologically excavated slips would help us to learn more about their distribution.

The Zhejiang University slips neither have verso lines nor notches - according to common opinion clearly arguments against their authenticity.

\subsection{Writing}

Palaeography is certainly the softest of the 'auxiliary' disciplines, not only in terms of Chinese written artefacts. ${ }^{110}$ Recent advances in tools provided by computer science have not yet become part of the mainstream, thus leaving judgement to the scholarly experts. Western authors sometimes use 'connoisseurship' to refer to the knowledge these scholars have, but this has a rather pejorative ring to it. It might be more appropriate to call it experience, as Drège has done, and reserve the other term for amateurs. By handling artefacts over the years, scholars, curators and librarians come to acquire first-hand knowledge of such objects that cannot be gained from merely ruminating on them. This does not mean, of course, that practical experience of this kind is always reliable and should not be open to criticism.

The approach called calligraphic above stills informs many of the judgements passed on ancient manuscripts. Part and parcel of this approach is the assumption of a mono-linear, ubiquitous genesis of script styles: Chu is followed by Qin, which, in turn, is followed by Han, which then developed sub-types over the centuries, and this development has been the same everywhere. This model clearly mirrors the imperial state with its central administration, but we simply do not know how effective it was in its early phase. This model could therefore be anachronistic. The dating of artefacts is mainly based on this assumption in many cases, but the situation actually may have been much messier. In the study of art and archaeology, non-synchronous developments of style have been known for

108 See Staack 2017b.

109 Hubei sheng Jing Sha tielu kaogudui 1991, 4.

110 Western palaeography and forensic science have developed their own approaches, some of which might be helpful in the study of Chinese writing as well. See Sirat 2006 on the former, for example, and Nickell 1996 and Koppenhaver 2007 on the latter. 
a long time, regardless of whether the reasons for them are regional, religious or political. It has been shown that the Chu script only differs from the script used in other media and states in minor respects. ${ }^{111}$ Since the central power of the Qin empire perished before the empire could establish itself firmly and the Han empire only controlled half of its territory in the first decades of its rule, it is actually more likely that regional and other traditions continued to co-exist until well into the second century BCE at least. Most of the unprovenanced manuscripts are dated to exactly this period, namely the late fourth to the second century BCE.

Some scholars still seem to assume that the palaeographic evidence was produced by a more or less homogenous group of scribes. In 1998, however, the writing found on the Guodian manuscripts was described by the eminent palaeographer Qiu Xigui 装錫圭 as 'crude, with many basic mistakes in the characters, suggesting that the scribes were not highly educated' and indicating 'incompetence'. Li Xueqin drew attention to some of the Shanghai Museum's slips having 'a high standard of calligraphy, which indicates the scribes were highly skilled professionals', but he also referred to 'basic mistakes' they had made, which could be 'attributed to carelessness or simply irresponsibility'. ${ }^{112}$ Regardless of whether the scribes were professionals or lacked education, mistakes in writing were to be found everywhere. What exactly were the standards for 'correct' writing? What were the criteria for committing a mistake? And who produced these artefacts? Were the scribes members of the hereditary offices known from ancient literature?

The Statutes for Scribes (Shi lü 史律) found in a tomb closed in 186 BCE stipulate that, in principle, scribes employed in the administration were trained as apprentices in their families and were tested on their proficiency in eight styles of writing, but the expanding empires needed many more scribes than the traditional families could supply. This led to an 'opening of the scribal profession' beyond the hereditary profession and the emergence of 'administrative literacy'. ${ }^{113}$ Recent research has brought to light that broken or erased slips were used for practising writing. ${ }^{114}$ Some of the arguments put forth against the slips of Zhejiang University might thus be invalidated: faulty writing on broken slips may simply represent exercises and not a lack of competence on the part of a forger. ${ }^{115}$

111 See Park 2016.

112 Allan/Williams 2000, 134 and 133, n. 22: 'The identity of the scribes was not a specific topic of discussion'.

113 Ma Ts. W. 2017, 301-304.

114 Guo 2019, 341.

115 Foster 2017, 180. 
Why exactly those pieces of writing would have been thought worthy to follow the owner into his tomb is another question, of course. Some of the ancient Chinese manuscripts or fragments thus might be closer to what papyrology deals with than the tradition of literary transmission investigated in Classical Studies, but without knowing more about scribal practices of the time, we can do little more than speculate. ${ }^{116}$

All this suggests it might be helpful to jettison the anachronistic calligraphic model and consider a basic distinction developed by Latin palaeographer Bernhard Bischoff (1906-1991). William G. Boltz has applied this distinction between 'book hand' and 'casual writing' or 'refined' and 'utilitarian' to Chinese manuscripts. In principle, it does not necessarily signify a distinction between different levels of competence by the producers, but signifies different statuses for the artefact - writings executed in book hand signify higher status than those in casual or cursive hands. One of the surprising results of applying this distinction to ancient Chinese manuscripts is the fact that some of the funeral texts like the inventories are produced in much higher 'calligraphic' quality than those literary texts modern scholars are interested in. ${ }^{117}$ This phenomenon cannot be explained by palaeography alone, but has to be seen in a broader archaeological context. $^{118}$

A discomforting observation was made by Peng Hao, namely 'unusual features in character structure in texts that have different calligraphy', meaning that some characters do not match the 'style' of the main body of writing. If this stands the test and is not a singular phenomenon, it will have consequences for the reconstruction of manuscripts as well as for the identification of scribal hands. ${ }^{119}$ The fact that slips written by another hand than the main scribe's were inserted into manuscripts raises similar concerns. ${ }^{120}$ In one scientifically excavated legal manuscript from the second century BCE, at least three different hands have been identified, and a mathematical manuscript from the same tomb was written by two hands with different tasks. ${ }^{121}$ What is the reason for this and how widespread were such practices?

116 See Ma Ts. W. 2017 for a detailed analysis of the findings at Xuanquan 懸泉 in Gansu province.

117 Boltz 2012-2013 on the manuscripts from Guodian 1.

118 See B. Wang 2020 for a selective but systematic survey of the archaeological context of manuscripts recovered from tombs.

119 Allan/Williams 2000, 134.

120 Feng 2017, 189.

121 Tomb Zhangjiashan 247 again; see Morgan/Chemla 2018. 
Modern scholars compare individual characters in order to identify or distinguish particular hands. Providing all occurrences of one character in a manuscript are taken into consideration, this method can work quite well. ${ }^{122}$ In many cases, however, just a few occurrences are selected in order to support an argument. This makes it rather difficult to arrive at safe conclusions in the case of very large manuscripts with a restricted vocabulary from an administrative background where writing must have been standardised to a certain degree. Furthermore, writing not only means producing one 'atomic' unit after the other, but it involves more or less continuous movement of the individual's hand. In the study of modern signatures, this characteristic style is called 'physiological habit', which the individual cannot abandon and unconsciously sticks to even if he or she wants to deceive the reader. It can therefore allow us to identify the originator if these traits are already known. ${ }^{123}$ Now, the reader may remember Harrist's words quoted above, namely that by 'repeatedly copying a piece of calligraphy of another writer, a calligrapher internalizes that person's style'. What 'copying' means in calligraphy and the other arts is copying a writer's or painter's 'physiological habit', which is widely thought to be individual and unchangeable. ${ }^{124}$ How long would a skilled calligrapher need to 'internalise' the style of writing that an ancient scribe employed? Hu Pingsheng's remark that very good fakes have appeared on the art and antique market since 2008 should not be forgotten. Hopefully, it is just a coincidence that some major corpora of unprovenanced manuscripts were acquired that same year.

\subsection{Content}

In his critique of the textual approach, Mai accused some scholars of exclusively relying on the content to identify fakes in a malicious way: if the content of a manuscript is known, it is copied; if not, it is made up. ${ }^{125}$ Even if this statement is overly apodictic, it still points to a fundamental problem. The period to which the unprovenanced manuscripts have been dated is not known very well: there are only a few literary sources available, and these often have widely differing

122 See Morgan/Chemla 2018, 158-160 for an assessment of earlier attempts at a 'graphological' analysis of single characters.

123 G. Wang 2019; see Mohammed 2020 for a tool that is not based on individual characters.

124 This is how Han van Meegeren was able to produce new Vermeer paintings and how Zhang Daqian created new works of the masters of bygone centuries, deceiving everyone, including the critics; see the introduction to this volume.

125 Mai 2019. 
interpretations. Archaeological evidence has already shown us more than once that most of them present partial views that are partisan. ${ }^{126}$ The chances of finding materials that neither fit in with literary evidence nor our present ideas of the past are high. If such materials are scientifically excavated, no one will doubt them, but if they happen to surface on the antique market, debates about their authenticity are sure to follow.

Criticising what he called the 'positivist paradigm' in art history, which would include the calligraphic approach exemplified by $\mathrm{Hu}$ Pingsheng in our case, Jerome Silbergeld stated the following back in 1999:

What this positivist paradigm does not prepare us for, it seems to me, is the possibility that some very fine forgeries might seem to us, in our imperfect state of knowledge, even more real, even more authentic, than the real thing; that some copywork or pastiche might seem even more true to its subject than the original. Conversely, we might misjudge some authentic but anomalous works that come along because they radically disrupt our current understanding of what is normal in, let us say, tenth-century painting style and because they require a thorough redefinition of that norm. ${ }^{127}$

The consequence of this for forgers is clear: either copy works that are already known (with a few slight modifications) or modify or re-write known texts, thus producing a new 'work'. Imagine stock phrases or patches of text from transmitted works being 'copied and pasted' and configured anew. While discussing the content of some of the Shanghai Museum manuscripts, it was noted that many of the 'new' philosophical or historical texts were not actually as new as they seemed to be, as most of their content was already familiar from received literature. ${ }^{128}$ This observation confirms the claim made above that scholars' historiographical approach influences the study of the content in the artefacts. Whenever archaeologists unearth new materials, 'everything after the inception of the Neolithic - the period corresponding with the time of Sima Qian's mythical rulers - is, to the traditional Chinese scholars, potentially the subject of textuallybased inquiry'. ${ }^{129}$ The Han-era historian Sima Qian (c. 140-c. 85 BCE) presented a mono-linear sequence of rulers and dynasties up to his own time. Li Xueqin's chronology project actually tried to prove the existence of the Xia, one of these prehistoric 'dynasties'. ${ }^{130}$

126 Selbitschka 2011.

127 Silbergeld 1999, 164.

128 Hans van Ess in a lecture at CSMC on 31 October 2013.

129 Selbitschka 2015, 7 quoting Falkenhausen 1993, 841.

130 Selbitschka 2015; whether or not this approach should be understood as nationalist, regionalist or traditionalist is of little importance here. 
An archaeologist like Peng Hao has an important voice in the study of ancient manuscripts, but this cannot belie the fact that the majority of scholars involved in this field are philosophers, intellectual and other historians, integrating the new material evidence into their textual cosmos. They interpret and re-interpret concepts, sentences and texts in the context of literary transmission, thus focussing on a small segment of the much richer world of ancient knowledge and knowledge practices. Whether provenanced or not, ancient manuscripts help to recover domains eliminated from transmission, such as law, administration, medicine, mathematics or divination. These domains were probably much more significant for contemporary everyday life than Confucian or other lore, which played a local or regional role at most before the late second century BCE. In addition, the archaeological evidence allows us to reconstruct practices no longer visible in later unified accounts produced by a central court. ${ }^{131}$ The study of these manuscripts is in the hands of a small number of experts, however.

The hierarchy of the content found in manuscripts is evident: literary texts occupy the highest place, legal and practical texts follow, and administrative documents, which are plentiful, are at the bottom of this pyramid. Forgers would naturally be less interested in producing everyday documents than philosophical texts, unless they had authentic documents among which the fake ones could be hidden. ${ }^{132}$ By default, then, manuscripts containing legal stipulations and rulings are more likely to be genuine than those containing philosophical texts. Archaeological evidence is not accepted as such, but only as 'collateral'.

\subsection{Scholars and forgers}

Librarians have become thieves stealing books that are in their custody, curators have done the same with works of art, and scholars have turned into criminals as well. As the contributions to the present volume show, scholars have stolen ideas and forged evidence at all times and in all places. Their motives may differ and the impact of their activities may be felt to varying degrees, but it is either naïve or arrogant, or both, to assume that 'true' scholars were and are immune to the temptation of meddling with their sources. What's more, the faking industry is different to the tomb-looting business. While very practical skills are required for the latter, the former employs artisans and craftspeople, many of whom have a

131 See Harper 2016 and Chemla 2018, among others.

132 Which seems to happen quite often in the case of cuneiform clay tablets, as Cécile Michel has pointed out to me. 
background in the arts or in scholarship. As science progresses, so does the art of faking. Some scholars seem to assume that forgers are illiterate, but in other countries convicted forgers have often been well-educated and well-read people, making them much closer to their own sphere than scholars would like to acknowledge. The study of literature on authentication would be part of their job anyway. It is only natural, therefore, that the quality of fakes should continue to improve, as $\mathrm{Hu}$ Pingsheng has also noted. Furthermore, looted manuscripts only need the assurance that they were excavated, exported, re-imported and constitute artefacts of high cultural and national value to be marketable to collectors around the world. This is an effective substitute for the provenance which has to be created in other cases.

Even scientifically excavated corpora may not be beyond doubt, however, as early rescue operations in particular were carried out under extremely challenging conditions: over a short period of just two or three weeks, a handful of professional archaeologists had to uncover huge tombs with the help of unskilled labourers. In some cases, scientifically excavated manuscripts disappeared after the very first report. In others, decades went by before they were published, and in other cases a report will probably never appear. ${ }^{133}$ In principle, it can neither be ruled out that genuine objects were taken from such excavations and sold on the antique market nor that fake artefacts were slipped into scientific excavations, thus 'establishing a context' for them. ${ }^{134}$

On the other hand, scholars are involved in the art and antique market. Their expertise is needed to authenticate artefacts, and it is not improbable that they are remunerated for their advice. If a well-known scholar judges an object to be genuine, then its value is sure to rise. Ancient manuscripts are not comparable to calligraphic works that fetch millions of dollars, of course, but there is profit in this trade, too. Hu noted that a dealer had asked 750 yuan for the manuscripts later acquired by Tsinghua University and Peking University, which was approximately US $\$ 105$ at the time - per slip. The Qin legal manuscripts purchased by the Yuelu Academy were cheaper (500 yuan/US\$70), probably because there was little demand in this specialised field of study. Hu does not disclose how much was paid in the end, ${ }^{135}$ but serious crimes have been committed for much less than 200,000 dollars.

133 The findings from tomb Huxishan 虎溪山 1 in Hunan province (excavated in 1999) still await publication; for an 'unfortunate tomb' see van Els 2009.

134 See Craddock 2016, 16-17.

$135 \mathrm{Hu} 2010,102$. 


\subsection{Ethics}

Looting and illegal artefact trafficking are prohibited all over the world now, and everyone involved in it can expect to be punished severely. Chinese scholars know this as a matter of course and have discussed the dilemma posed by the appearance of unprovenanced cultural heritage on the international art and antique market. As far as ancient manuscripts are concerned, two arguments in favour of their acquisition are put forward. First, the condition of them, which is very poor; without immediate treatment, they may get damaged beyond repair. Second, if they are not repatriated, they may go to other countries. ${ }^{136} \mathrm{Hu}$ Pingsheng warned that private collectors should be dissuaded from buying ancient artefacts, as this group of buyers constitutes the main audience for the tomb raiders. He reports using two arguments to this end: first, private collectors do not have the expertise and the technical means to deal with the poor state of these manuscripts, thus endangering their very existence; second, because of their lack of expertise, it is very likely that they will fall prey to forgers. A handbook on the scientific investigation of fakes pursues the same line: 'Unfortunately, the likelihood that a piece has been stolen or looted does not seem to deter purchasers; the possibility that it is forged does'. ${ }^{137}$

Most scholars do not seem to have any scruples about using unprovenanced manuscripts for their research. In 2013, however, Paul R. Goldin correctly pointed out 'that the study of an unprovenanced manuscript from most other parts of the world would be frowned upon - and some academic journals might, on principle, refuse to consider articles' like his own on one of the Shanghai Museum manuscripts, in which he voices these concerns. He concludes that 'scholars must not contribute to the sale of looted antiquities by providing authentication and expertise, and that by referring to such objects in print, we inescapably provide authentication and expertise'. ${ }^{138}$ Foster has presented arguments justifying the study of unprovenanced manuscripts in general beyond his own research on one of the Peking University manuscripts. He suggests

to weigh between, on the one hand, the material and intellectual losses that may be suffered in the future by further incentivizing looting and, on the other hand, the material and

$136 \mathrm{Hu} 2010,105-106$.

137 Craddock 2016, 21.

138 Goldin 2013, 157-158. 
intellectual losses we will suffer imminently by neglecting looted artifacts already on the market, as well as the future loss of neglecting those that may surface later. ${ }^{139}$

What Foster means here is that the handful of scholars in the West seriously studying ancient Chinese manuscripts have little or no impact on the field, which is dominated by colleagues from East Asia, even if the occasional appearance of Western scholars at a conference might lend prestige to the collections of unprovenanced manuscripts. There is no indication at all, however, that Chinese academia will terminate their work just because some scholars in the West tell them to. The second argument concerns a heightened awareness of the value of bamboo manuscripts. Since many robbers were looking for valuable works of art in the 1990s, such as ancient bronze vessels, they left the manuscripts behind or even let them burn. This kind of loss might be prevented in the future by teaching the robbers not to disregard the slips, thus giving them 'a chance to survive for future generations', ${ }^{140}$ if only as an incidental catch. This pragmatic argument would certainly not satisfy Goldin, but there is yet another facet to it.

Goldin claims: 'If one wants to study excavated artifacts, there are plenty of properly excavated materials still awaiting thorough investigation'. ${ }^{141}$ Indeed, there are many provenanced manuscripts that have not been fully explored yet. The only problem is that results from research on unprovenanced manuscripts have infiltrated all the related fields since the late 1990s, from palaeography to intellectual history. If one took Goldin's approach seriously, then many aspects of ancient Chinese history would be anathema or be reset to the state the field was in twenty years ago, because there is little chance any more of disentangling the results obtained from genuine finds and dubious evidence. ${ }^{142}$

At the end of the day, this might just call for a return to basic scholarly virtues: a critical examination of all the evidence while not taking too much for granted. The ethical issue, however, will have to be resolved by every scholar individually.

139 Foster 2017, 233.

140 Foster 2017, 238.

141 Goldin 2013, 158. In this article, Goldin first discusses textual problems in an unprovenanced manuscript before advising the reader not to do so and blaming the German Research Foundation (DFG) for funding a project on the Yuelu collection; two volumes edited by him include articles using such artefacts: Goldin 2017 and Goldin 2018.

142 I am grateful to Ondřej Škrabal for pointing this out to me. 


\section{Concluding remarks}

We will possibly never know for certain whether the unprovenanced manuscripts held by public institutions in China are fakes. As long as scientific analyses remain as cursory and ill-documented as they are at present, the shadows of doubt will not disperse, and judgement will remain an exercise in philology and history. Since the period under scrutiny is little known with the exception of few literary sources, scholars' decisions are even more tentative than they are anyway. While the calligraphic approach is slowly giving way to palaeographic study, the historiographical approach is still dominant.

The prosecution of tomb looting in China in recent years may help to discourage potential robbers. Will it also deter potential forgers from producing fake manuscripts, though? Even if this may not work for private collectors, there have been no reports on new acquisitions of unprovenanced written artefacts by public institutions since 2015. And this, at least, is promising.

\section{References}

Allan, Sarah (2015), Buried Ideas: Legends of Abdication and Ideal Government in Early Chinese Bamboo-Slip Manuscripts, New York: SUNY Press.

Allan, Sarah and Crispin Williams (eds) (2000), The Guodian Laozi: Proceedings of the International Conference, Dartmouth College, May 1998, Berkeley: The Society for the Study of Early China.

Barbieri-Low, Anthony J. and Robin D.S. Yates (2015), Law, State, and Society in Early Imperial China: A Study with Critical Edition and Translation of the Legal texts from Zhangjiashan Tomb no. 247, vol. 2, Leiden: Brill.

Barboza, David, Graham Bowley, and Amanda Cox (2013), 'Forging an Art Market in China', in New York Times, 28 October, <www.nytimes.com/projects/2013/china-artfraud/index.html (accessed on 1 April 2020).

Beijing daxue chutu wenxian yanjiusuo 北京大學出土文獻研究所 (2009), 'Gongzuo jianbao' 工作簡報 2, <zggds.pku.edu.cn/005/007/002.pdf〉 (accessed on 8 April 2020, but not available when checked on 27 June 2020).

Beijing Wulun guoji paimai youxian gongsi (2019), Wulun 2019 nian chunji wenwu yishupin paimaihui 伍倫2019年春季文物藝術品拍賣會, Beijing: Beijing Wulun guoji paimai youxian gongsi.

Boltz, William G. (2012-2013), 'Hand-Writing Styles in Early Chinese Manuscripts', in manuscript cultures, 5: 11-19.

Buswell, Robert E. Jr. (ed.) (1990), Chinese Buddhist Apocrypha, Honolulu: University of Hawaii Press.

Cao Jinyan 曹錦炎 (ed.) (2011): Zhejiang daxue cang Zhanguo Chu jian 浙江大學藏戰國楚簡, Hangzhou: Zhejiang daxue. 
Chemla, Karine (2018), 'Mathematics', in Paul R. Goldin (ed.), Routledge Handbook of Early Chinese History, London/New York: Routledge Taylor, 473-492.

Chen Songchang 陳松長 (2001), Xianggang Zhongwen daxue wenwuguan cang jiandu 香港中 文大學文物館藏簡牘, Hong Kong: Xianggang Zhongwen daxue wenwuguan.

Chen Songchang 陳松長 (2009), 'Yuelu shuyuan suo cang Qin jian zongshu’ 获麓書院所藏秦簡 綜述, in Wenwu 文物, 3: 75-88.

Cohen, Monique (2002), 'Genuine or fake?', in Whitfield (ed.), 22-32.

Craddock, Paul (2016), Scientific Investigation of Copies, Fakes and Forgeries, London/New York: Routledge.

Drège, Jean-Pierre (2002), 'Random notes on Dunhuang forgeries', in Whitfield (ed.), 41-50.

Drège, Jean-Pierre (2017), Le papier dans la Chine impériale. Origines, fabrication, usages, Paris: Les Belles Lettres.

van Els, Paul (2009), 'Dingzhou: The Story of an Unfortunate Tomb', in Asiatische Studien/Études Asiatiques, 63/4: 909-941.

Falkenhausen, Lothar von (1993), 'On the Historiographical Orientation of Chinese Archaeology', in Antiquity, 67/257: 839-849.

Falkenhausen, Lothar von (2013), 'Antiquarianism in East Asia: A Preliminary Overview', in Alain Schnapp (ed.), World Antiquarianism: Comparative Perspectives, Los Angeles: Getty Research Institute, 35-66.

Fang Beisong 方北松 and Tong Hua 童華 (2010), ‘Jiance baogao jian'ce 檢測報告’, in Zhu Hanmin 朱漢民 and Chen Songchang 陳松長: Yuelu shuyuan cang Qin jian (yi) 获麓書院藏 秦簡(壹), Shanghai: Shanghai Cishu, 197-201.

Fang Beisong 方北松, Li Meiying 李梅英 and Tong Hua 童華 (2012), 'Zhu yangpin laohua chengdu duibi fenxi’ 竹樣品老化程度對比分析, in Qinghua daxue chutu wenxian yanjiu yu baohu zhongxin 清華大學出土文獻研究與保護中心, Beijing daxue chutu wenxian yanjiusuo 北京大學出土文獻研究所 and Jingzhou wenwu baohu zhongxin 荊州文物保護 中心 (eds), Gudai jiandu baohu yu zhengli yanjiu 古代簡牘保護與整理研究, Shanghai: Zhongxi, 338-341.

Feng Shengjun (2017), 'Scribal influence on the transmission of pre-Qin texts, as seen in excavated manuscripts', in Chinese Studies in History, 50/3: 185-198.

Fischer, Paul (2008-2009), 'Authentication Studies (辨偽學). Methodology and the Polymorphous Text Paradigm', in Early China, 32: 1-43.

Fölster, Max Jakob (2015), 'Introduction to the History, Use and Function of Chinese Book Collectors' Seals', in manuscript cultures, 8: 25-52.

Forke, Alfred (1907), Lun-hêng. Part I: Philosophical Essays of Wang Ch'ung, Berlin: Walter de Gruyter.

Foster, Christopher J. (2017), 'Introduction to the Peking University Han Bamboo Strips: On the Authentication and Study of Purchased Manuscripts', in Early China, 40: 167-239.

Friedrich, Michael (1996), 'Zur Datierung zweier Handschriften des Daode jing', in TextKritische Beiträge, 2: 105-117.

Ge, Celine (2015), 'China's ancient treasures under siege from army of tomb raiders', in South China Morning Post, 4 December, <www.scmp.com/lifestyle/article/1885832/chinasancient-treasures-under-siege-army-tomb-raiders (accessed on 10 April 2020).

Giele, Enno (2006), Imperial Decision-Making and Communication in Early China. A Study of Cai Yong's Duduan, Wiesbaden: Harrassowitz.

[Giele, Enno] (2014), Manuscripts Database, <projects.zo.uni-heidelberg.de/manuscript/ index.php/> (accessed on 4 April 2020). 
Goldin, Paul R. (2013), 'Heng Xian and the Problem of Studying Looted Artifacts', in Dao, 12: 153-160.

Goldin, Paul R. (ed.) (2017), A Concise Companion to Confucius, Hoboken N): Wiley-Blackwell. Goldin, Paul R. (ed.) (2018), Routledge Handbook of Early Chinese History, London: Routledge.

Guo Weitao 郭偉濤 (2019), ‘Bunken to ibutsu no kyōkai: Chūgoku shutsudo kandoku shiryō no seitaiteki kenkyū 文献と遺物の境界: 中国出土簡牘史料の生態的研究, edited by Momiyama Akira 籵山明; Satō Makoto 佐藤信', in Bamboo and Silk, 2: 339-356.

Han Wei 韓巍 (2012), ‘Xi Han zhushu Laozi jianbei huahen de chubu fenxi’西漢竹書 《老子》簡背劃痕的初步分析, in Beijing daxue chutu wenxian yanjiusuo 北京大學出土文 獻研究所 (ed.), Beijing daxue cang xi Han zhushu (er) 北京大學藏西漢竹書（武）, Shanghai: Shanghai guji, 227-235.

Harper, Donald (2016), 'The Textual Form of Knowledge: Occult Miscellanies in Ancient and Medieval Chinese Manuscripts, $4^{\text {th }}$ Century BCE to $10^{\text {th }}$ Century CE', in Michael Friedrich and Cosima Schwarke (eds), One-Volume Libraries: Composite and Multiple-Text Manuscripts, Berlin/Boston: De Gruyter, 305-354.

Harrist, Robert E. Jr. (2004), 'Replication and Deception in Calligraphy of the Six Dynasties Period', in Zong-qi Cai (ed.), Chinese Aesthetics. The Ordering of Literature, the Arts and the Universe in the Six Dynasties, Honolulu: University of Hawai'i, 31-59.

Helman-Ważny, Agnieszka (2016), 'More than meets the eye: Fibre and Paper Analysis of the Chinese Manuscripts from the Silk Roads', in STAR: Science \& Technology of Archaeological Research, 2/2:127-140.

Hu Dongbo 胡東波, Zhang Qiong 張瓊 and Wang Kai 王恺 (2011), 'Beida Xi Han zhu jian de keji fenxi' 北大西漢竹簡的科技分析, in Wenwu 文物, 6:90-93.

Hu Pingsheng 胡平生 (2010), 'Lun jianbo bianwei yu liushi jiandu qiangjiu' 論簡帛辨偽與流失 簡牘搶救', in Chutu wenxian yanjiu 出土文獻研究, 10: 76-108.

Huang Dekuan 黃德寬 and Xu Zaiguo 徐在國 (2019), Anhui daxue cang zhanguo zhujian yi 安徽 大學藏戰國竹簡一, Shanghai: Zhong Xi.

Hubei sheng Jing Sha tielu kaogudui 湖北省荊沙鐵路考古隊 (1991), Baoshan Chu jian 包山楚簡, Beijing: Wenwu.

Jang, Scarlett (2016), 'The Culture of Art Collecting in Imperial China', in Martin J. Powers and Katherine R. Tsiang (eds): A Companion to Chinese Art, Chichester: John Wiley \& Sons, 47-72.

Jiang Guanghui 姜廣輝 (2009), ““Qinghua jian” jianding keneng yao jingli yige changqi guocheng - zai tan dui “Bao xun” de yiwen’ “清華簡” 鑒定可能要一個長期過程一一再 談對《保訓》篇的疑問, in Guangming ribao 光明日報 8 June, <www.gmw.cn/01gmrb/2009-06/08/content_931257.htm〉 (accessed on 8 April 2020).

Jiao Ao 焦傲 (2019), Zhou Shaoliang xiansheng yu Dunhuang xue 周紹良先生與敦煌學, Beijing: Beijing Wulun guoji paimai youxian gongsi.

Jie Xiangyong 節祥雍 (ed.) (1984), Fashu yaolu 法書要錄, Beijing: Renmin meishu.

Jingzhou bowuguan 荊州博物館 (2020), 'Hubei Jingzhou shi Hujia caochang mudi M12 fajue jianbao’ 湖北荊州市胡家草場墓地M12發掘簡報, in Kaogu 考古, 2: 3-20.

Johnson, Wallace (1997), The T'ang Code, Vol. II: Specific Articles, Princeton/NJ: Princeton University Press.

Kolb, Raimund T. (2006), ““̈̈beltäter, Rächer und Rebellen”. Die han-zeitlichen “Jungen Männer” (shaonian)', in Michael Friedrich et al. (eds): Festschrift für Hans Stumpfeldt aus Anlaß seines 65. Geburtstages, Wiesbad en: Harrassowitz, 425-442. 
Koppenhaver, Katherine M. (2007), Forensic Document Examination: Principles and Practice, Totowa N): Humana Press.

Koselleck, Reinhart (1977), 'Standortbindung und Zeitlichkeit. Ein Beitrag zur historiographischen Erschließung der Welt', in Reinhart Koselleck et al. (eds), Objektivität und Parteilichkeit in der Geschichtsschreibung, Munich: dtv, 17-46.

Lau, Ulrich and Michael Lüdke (2012), Exemplarische Rechtsfälle vom Beginn der Han-Zeit: Eine kommentierte Übersetzung des Zouyanshu aus Zhangjiashan/Provinz Hubei, Tokyo:

Research Institute for Languages and Cultures of Asia and Africa (ILCAA), Tokyo University of Foreign Studies.

Lau, Ulrich, and Thies Staack (2016), Legal Practice in the Formative Stages of the Chinese Empire: An Annotated Translation of the Exemplary Qin Criminal Cases from the Yuelu Academy Collection, Leiden: Brill.

Ledderose, Lothar (1984), 'Some Taoist Elements in the Calligraphy of the Six Dynasties', in T'oung Pao, 70: 246-278.

Li Ling (2020), The Chu Silk Manuscripts from Zidanku, Changsha (Hunan Province), translated and edited by Lothar von Falkenhausen, Hong Kong: The Chinese University of Hong Kong.

Li Rui 李銳 (2004): “'Sunzi bingfa” xianshen yu wangshang zhenjia gu bingfa zai qi bolan’

《孫子兵法》現身于網上 真假古兵法在起波瀾, in Chenbao 晨報, in Souhu xinwen 搜狐新聞 15 October, <news.sohu.com/20041015/n222499919.shtml〉 (accessed on 9 May 2020).

Li Xueqin (2002), 'The Xia-Shang-Zhou Chronology Project: Methodology and Results', in Journal of East Asian Archaeology, 4/1: 321-333.

Li Xueqin 李學勤 (ed.) (2010), Qinghua daxue cang zhanguo zhujian (yi) 清華大學藏戰國竹簡 (壹), Shanghai: Zhong-Xi.

Li Xueqin and Liu Guozhong (2010), 'The Tsinghua Bamboo Strips and Ancient Chinese Civilization', in Journal of Chinese Philosophy, 37: 6-15.

Liu Guozhong (2016), Introduction to the Tsinghua Bamboo-Strip Manuscripts, transl. by Christopher J. Foster and William N. French, Leiden/Boston: Brill.

Liu Wendian 劉文典. (ed.) (1989), Huainan honglie jijie 淮南鴻烈集解, 2 vols., Beijing: Zhonghua.

Loewe, Michael (2015), 'Liu Xiang and Liu Xin', in Michael Nylan and Griet Vankeerberghen (eds), Chang'an 26 BCE: An Augustan Age in China, Seattle: University of Washington Press, 369-389.

Lorusso, Vito et al. (2015), 'Searching for a definition of “manuscript”', <www.manuscriptcultures.uni-hamburg.de/papers_e.html (accessed on 22 April 2020).

Ma Chengyuan 馬承源 (ed.) (2001), Shanghai bowuguan cang Chu zhujian (yi) 上海博物館藏楚 竹簡 (一), Shanghai: Shanghai guji.

Ma, Tsang Wing (2017), 'Scribes, Assistants, and the Materiality of Administrative Documents in Qin-Han Early China: Excavated Evidence from Liye, Shuihudi, and Zhangjiashan', in T'oung Pao, 103/4-5: 297-333.

Mai Di 麥笛 (2019), 'Weishenme shuo Qinghua jian Anda jian juefei weijian - qiantan jiandu de bianwei’ 為什麼說清華簡安大簡決非僞簡一淺談簡片的辨僞, in Zhonghua dushubao 中華讀書報 4 December, <epaper.gmw.cn/zhdsb/html/2019-12/04/nw.D110000 zhdsb_20191204_1-09.htm> (accessed on 15 April 2020).

Mohammed, Hussein (2020), Handwriting Analysis Tool v3.0 (HAT3), <doi.org/10.25592/uhhfdm.902〉. 
Morgan, Daniel Patrick and Karine Chemla (2018), 'Writing in Turns: An Analysis of Scribal Hands on the Bamboo Manuscript Suan shu shu 算數書 (Writings in Mathematical Procedures) from Zhangjiashan Tomb No. 247', in Bamboo and Silk, 1: 152-190.

Museum für Asiatische Kunst (2007), Die Kunst des Fälschens, Berlin: Staatliche Museen zu Berlin - Stiftung Preußischer Kulturbesitz.

Nickell, Joe (1996), Detecting Forgery: Forensic Investigation of Documents, Lexington: The University Press of Kentucky.

Nivison, David S. (2002), 'The Xia-Shang-Zhou Chronology Project: Two Approaches to Dating', in Journal of East Asian Archaeology, 4/1: 359-366.

Nylan, Michael and Griet Vankeerberghen (eds) (2015), Chang'an 26 BCE: An Augustan Age in China, Seattle: University of Washington.

Park, Haeree (2016), The Writing System of Scribe Zhou, Berlin/Boston: De Gruyter.

Robinet, Isabelle (1993), Taoist Meditation, The Mao-shan Tradition of Great Purity, transl. by Julian F. Pas and Norman J. Girardot, New York: SUNY Press.

van Schaik, Sam and Imre Galambos (2012), Manuscripts and Travellers: The Sino-Tibetan Documents of a Tenth-Century Buddhist Pilgrim, Berlin/Boston: De Gruyter.

Selbitschka, Armin (2011), 'Text and Tombs: A Fragile Relationship', in China Review International, 18/4: 444-449.

Selbitschka, Armin (2015), 'The Pitfalls of Second-hand Information: On the Traditionalist Dogma in Chinese Excavation Reports', in Bulletin of the Museum of Far Eastern Antiquities, 79-80, 5-50.

Sena, Yunchiahn C. (2019), Bronze and Stone: The Cult of Antiquity in Song Dynasty China, Seattle: University of Washington Press.

Shaughnessy, Edwin L. (2008), 'Chronologies of Ancient China: A Critique of the "Xia-ShangZhou Chronology Project”, in Clara Wing-chung Ho (ed.), Windows on the Chinese World: Reflections by Five Historians, Lanham: Lexington Books.

Shaughnessy, Edwin L. (2011), 'Of Riddles and Recoveries: The Bamboo Annals, Ancient Chronology and the Work of David Nivison', in Journal of Chinese Studies, 52: 269-290.

Shen, Andrea (2001), 'Ancient script rewrites history', in The Harvard Gazette, 22 February, <news.harvard.edu/gazette/story/2001/02/harvard-gazette-ancient-script-rewriteshistory/> (accessed on 10 April 2020).

Silbergeld, Jerome (1999), 'The Referee Must Have a Rule Book: Modern Rules for an Ancient Art', in Judith G. Smith and Wen C. Fong (eds), Issues of Authenticity in Chinese Painting, New York: The Metropolitan Museum of Art, 149-169.

Sirat, Collette (2006), Writing as Handwork. A History of Handwriting in Mediterranean and Western Culture, Turnhout: Brepols.

Staack, Thies (2015), 'Identifying Codicological Sub-units in Bamboo Manuscripts: Verso Lines Revisited', in manuscript cultures, 8: 157-186.

Staack, Thies (2016), 'Reconstruction of Early Chinese Bamboo and Wood Manuscripts: A Review (1900-2010)', 〈www.manuscript-cultures.uni-hamburg.de/papers_e.html〉 (accessed on 5 April 2020).

Staack, Thies (2017a), 'Could the Peking University Laozi 老子 really be a forgery? Some skeptical remarks', <doi.org/10.11588/heidok.00022453>.

Staack, Thies (2017b), 'The Neglected "Backyard” of Early Chinese Manuscripts: How an Analysis of the Verso of Bamboo Slips can enable the Reconstruction of a Manuscript Roll', <doi.org/10.11588/heidok.00023213>. 
Storozum, Michael J. and Yuqi Li (2020), 'Chinese Archaeology Goes Abroad', in Archaeologies <doi.org/10.1007/s11759-020-09400-z>.

Strickmann, Michel (1977), 'The Mao shan Revelations: Taoism and the Aristocracy', in T'oung Pao, 63: 1-64.

Su Jinren 蘇晉仁 and Xiao Lianzi 蕭鍊子 (eds) (1995), Chu sanzang jiji 出三藏記集, Peking: Zhonghua.

Sun Peiyang 孫沛陽 (2011), ‘Jiance bei huaxian chutan’ 簡冊背畫線初探, in Chutu wenxian yu gu wenzi yanjiu 出土文獻與古文字研究, 4: 449-462.

Unger, Ulrich (1989), Glossar des klassischen Chinesisch, Wiesbaden: Harrassowitz.

Wang, Bin (2020), The Spatial Arrangement of Ancient Chinese Tomb Manuscripts ( $5^{\text {th }}$ $2^{\text {nd }}$ C. BCE): An Archaeological Survey, unpublished PhD thesis, University of Hamburg.

Wang, Guanping (2019), 'The status of Chinese handwriting identification and the improvement of methodologies', in Forensic Science and Criminology, 4: 1-7.

Whitfield, Susan (ed.) (2002), Dunhuang Manuscript Forgeries, London: The British Library.

Xia Jing 夏靜 (2013), 'Zhanguo Chu jian ru cang Wuhan daxue’ 戰國楚簡入藏武漢大學, in Guangming ribao 光明日報, 16 January 2013, <news.whu.edu.cn/info/1003/20068.htm> (last accessed on 4 May 2020).

Xia Nai 夏㑯 (1948), ‘Xinhuo zhi Dunhuang Han jian’ 新獲之敦煌漢簡, in Lishi yuyan yanjiusuo jikan 歷史語言研究所集刊, 19: 235-261.

Xing Wen 邢文 (2012), 'Zheda cangjian bianwei (xia)’ 浙大藏簡辨俀 (下), in Guangming ribao 光明日報, 4 June, <epaper.gmw.cn/gmrb/html/2012-06/04/nw.D110000gmrb_ 20120604_1-15.htm?div=-1> (accessed on 6 April 2020).

[Xu Lei 徐否] Nanpai sanshu 南派三叔 (2007), Daomu biji 盜墓筆記, Beijing: Zhongguo youyi.

Zhu Hanmin 朱漢民 and Chen Songchang 陳松長 (eds) (2010), Yuelu shuyuan cang Qin jian (yi) 获麓書院藏秦簡 (壹), Shanghai: Shanghai Cishu. 